\title{
Is tax return information useful to equity investors?
}

August 2017

\begin{abstract}
In this study, I examine whether tax return information is incrementally useful to equity investors relative to publicly-available information, such as financial statements. To test this relation, I exploit unique features of the syndicated loan market, as prior literature shows that lenders obtain tax returns from borrowers and that lenders' private information is transmitted to equity markets when institutional investors are part of a loan syndicate. I find economically significant increases in tax expense valuation and decreases in taxrelated market anomalies following the issuance of institutional syndicated loans, consistent with equity investors finding information about firm performance in tax returns that is useful for their trading decisions. I also document that tax returns are a valuable information source that can motivate institutional investor participation in loan syndicates. This study informs the important, ongoing policy debate over public disclosure of corporate tax return information and extends prior research by showing that investors use information from tax returns incremental to information in financial statements.
\end{abstract}

Keywords: Tax Return Information, Syndicated Loans, Tax Expense Valuation, Tax Anomaly Returns

JEL classification codes: G11, G14, M41, M48 


\section{Introduction}

Policymakers in the U.S. and abroad have been debating whether tax return information (TRI) should be made publicly available for as long as a corporate income tax system has been in place (Lenter et al. 2003; Morris 2015). ${ }^{1}$ For example, former Internal Revenue Service Commissioner Mark Everson has called for public disclosure of corporate tax returns, saying "Federal tax returns include important information about corporations beyond that available in financial statements. Making corporate returns available for public inspection would provide a powerful tool to analysts...[and] help others better evaluate counterparties and risk" (Everson 2008). Recent accounting research has also called for disclosure of some TRI, noting the difficulty in determining companies' tax positions from their financial statements and the difficulties investors have in valuing tax information (e.g., McGill and Outslay 2004; Hanlon 2005; Chi et al. 2014; Morris 2015). However, little empirical evidence exists regarding the benefits and costs of public tax return disclosure (Hasegawa et al. 2013; Bø et al. 2015; Hoopes et al. 2016). I fill this void by providing novel empirical evidence regarding a significant issue raised in this debate: Do equity investors find the information in tax returns useful; i.e., helpful for equity valuation? ${ }^{2}$

Prior literature has not examined the usefulness of tax return information to equity investors, although it does provide evidence that tax information contained in the financial statements can provide information about profitability (Hanlon et al. 2005; Ayers et al. 2009), earnings growth (Kim et al. 2015), and firm risk (Henry 2014; Dhaliwal et al. 2017) incremental to GAAP income. This evidence suggests that reported tax information contains unique information not contained in GAAP income, yet also raises the question: If this incremental information can be gleaned from tax information in the financial statements, will tax returns contain any additional information beyond that in financial statement tax disclosures?

\footnotetext{
${ }^{1}$ I define "tax return information" (TRI) as any information contained in a firm's tax return that is not normally contained in a firm's financial statements or other public disclosures.

${ }^{2}$ I define "usefulness" to investors as helping them value a firm more efficiently incremental to what they could without TRI, but with access to financial statements. Implicit in this definition is that investors use information rationally in their decision-making. This definition also does not distinguish between providing incremental valuerelevant information and simply helping investors better understand the information they already have access to, because in both cases TRI helps equity investors value a firm more efficiently.
} 
Tax returns may not contain additional information, or, to quote former Securities and Exchange Commission Chairman Harvey Pitt: “The tax disclosure in companies' financial statements is more beneficial in helping investors understand a company's tax situation than would be providing public access to tax returns" (Lenter et al. 2003, 806). At the same time, another stream of literature shows that there is information in the tax accounts reported in financial statements that equity investors do not use efficiently (Lev and Nissim 2004; Thomas and Zhang 2011) and that even sophisticated market participants, such as analysts, struggle to understand the information contained in the tax accounts (Plumlee 2003; Weber 2009). Given equity market participants' difficulty in processing reported tax information, this literature has called for firms to provide some information from their tax returns to investors (McGill and Outslay 2004; Hanlon 2005; Chi et al. 2014). However, the Tax Executives Institute has argued that providing TRI to investors could lead to significant misinterpretation and increased equity mispricing (TEI 2006). As such, it is unclear whether providing TRI to investors will provide them with incremental information that will assist them in more efficiently valuing firms.

A key reason why there is little empirical evidence to inform the debate over whether corporate TRI should be publicly disclosed is that there are few settings in which TRI disclosure can be examined, and even fewer settings without significant confounds and data limitations (Hasegawa et al. 2013; Hoopes et al. 2016). To overcome these issues, I rely on features of the U.S. syndicated loan market. ${ }^{3}$ Recent literature shows that lenders frequently request TRI when evaluating bank loan applications (Minnis and Sutherland 2017). Additionally, private information provided to lenders is frequently transmitted to equity markets, particularly when the syndicated loan is traded on secondary markets and the loan syndicate includes institutional investors such as hedge funds, mutual funds, insurance companies, and pension funds (Bushman et al. 2010; Ivashina and Sun 2011; Massoud et al. 2011; Addoum and Murfin 2016). This transmission could occur if institutional investor-lenders trade in a firm's equity based on private information, either directly or by following secondary loan market trading, or if their affiliated equity

\footnotetext{
${ }^{3}$ For brevity, hereafter all mentions of loans refer to syndicated loans unless otherwise denoted.
} 
analysts use this private information in their forecasting and investors rely on these forecasts. Although I am unable to directly observe the TRI transmitted, this setting avoids the issues that plague other settings where both investors and the public have access to TRI (see Section 2.1).

Drawing on prior research about lenders and syndicated loans, I expect that tax returns are conveyed to lenders, and that TRI is then conveyed to equity market participants, but only when the loan is traded by institutional investors on secondary loan markets. ${ }^{4}$ If equity investors find the TRI they receive in this situation useful, they are likely to change their valuation of tax expense, with an increase (decrease) in the valuation coefficient on tax expense suggesting that TRI provides additional information about firm performance (cash taxes paid) (Shevlin 2002; Hanlon et al. 2005; see also Appendix A). ${ }^{5}$ Additionally, investors likely value a firm's equity more efficiently as they incorporate the TRI in their trading decisions. Changes in equity valuation around the release of information has long been considered evidence of the usefulness of that information (Ball and Brown 1968).

I conduct two different but complementary analyses to test my research question. First, I measure differential valuation of tax expense by regressing equity returns on earnings that have been partitioned into pre-tax earnings and tax expense. Similar to earnings response coefficient analyses, I examine the tax expense response coefficient to identify how much firm performance information investors find in pre-tax earnings vs. tax expense. Additionally, this model reveals the type of information conveyed by TRI: When tax response coefficients are positive (negative), information about firm performance (cash tax payments) is the biggest source of investor reactions to tax information (Shevlin 2002; Hanlon et al. 2005). I also conduct this analysis after partitioning my sample into firms with high and low GAAP earnings quality, since TRI is likely more valuable to investors of firms with low GAAP earnings quality (Ayers et al. 2009).

Second, I examine changes in tax-related market anomalies. If investors find TRI useful as it is

\footnotetext{
${ }^{4}$ My empirical tests are joint tests of my hypothesis and these assertions, meaning I effectively test the validity of the "TRI" construct.

${ }^{5}$ I focus on trading with respect to financial-statement tax information since I cannot directly observe TRI, which should be positively correlated with financial-statement tax information. If tax returns help investors better understand the information they already have access to, then I am directly measuring the information investors are reacting to.
} 
transmitted from institutional investors in the lending syndicate to equity markets, they will likely trade more efficiently on the tax information in financial statements (Chen and Martin 2011). This increase in trading efficiency should occur if TRI provides investors new and value-relevant information, helps investors overcome behavioral biases that lead to market inefficiencies, or reduces various arbitrage costs and investors arbitrage away the newly-available net arbitrage gains. To measure trading efficiency with regards to tax information, I use the existence and size of market anomalies related to various tax metrics, including the imputed taxable income to book income ratio, book-tax differences, the tax change component of earnings, and tax expense surprises (Lev and Nissim 2004; Hanlon 2005; Schmidt 2006; Thomas and Zhang 2011). I focus on tax-related market anomalies, since it is unlikely that these anomalies would be materially affected by the provision of non-tax private information given to lending syndicates. I control for non-tax information that could be related to these anomalies (Hepfer 2016) and other characteristics previously shown to affect tax-related market anomalies, as well as use entropy-balancing to ensure my results are not driven by selection bias (Hainmueller 2012).

To empirically examine whether TRI is useful to investors, I use a difference-in-differences design on a sample of firms that borrow from a lending syndicate. The first difference is pre- vs. post-issuance of a syndicated loan and the second is whether or not the syndicated loan is an institutional loan, where information about the borrower (e.g., TRI) is more likely to be transmitted to equity markets through secondary loan markets. I restrict my sample to firm-years within a six-year window of borrowing through a syndicated loan to hold constant financing needs and choices for both treatment (institutional loan) and control (non-institutional loan) firms. If TRI is useful to investors, I predict that firms issuing institutional loans will experience an increase or decrease in tax-expense response coefficients following the issuance of the loan, depending on what type of information TRI conveys to investors. Any effect of TRI on taxexpense response coefficients should be concentrated among firms with lower earnings quality, as prior studies show that the incremental value of tax-related financial statement information is greatest for these firms (Ayers et al. 2009). I also predict that firms issuing institutional loans will experience a decrease in abnormal returns to tax-related market anomalies because useful TRI should help investors more efficiently 
value a firm relative to already-available information.

Results from the examination of tax response coefficients show that tax expense valuation increases following institutional loan issuances, consistent with tax returns providing incremental information about firm performance beyond the information already provided in financial statements. I find that this increase is concentrated among firms with lower earnings quality. In addition, results show that anomalies related to the imputed taxable income to book income ratio, negative book-tax differences, the tax change component of earnings, and tax expense surprises (Lev and Nissim 2004; Hanlon 2005; Schmidt 2006; Thomas and Zhang 2011) decrease following an institutional loan issuance, consistent with TRI helping equity investors more efficiently price a firm's equity. Together, these tests provide consistent evidence that TRI is useful to equity investors, contradictory to the claims of tax return disclosure opponents.

To verify that my results derive from access to incrementally useful TRI, I examine how my results vary around a significant exogenous change in tax return reporting: the introduction of Schedule M-3. This schedule, implemented for tax years ending on or after December 31, 2004, greatly increased the detail of book-tax difference disclosures within the tax return and represented "one of the most important new sources of information for the U.S. Treasury and the IRS in the last 40 years" (Donohoe and McGill 2011, 36). My results in regards to tax response coefficients suggest that investors who have access to the Schedule M-3 through institutional syndicated loans are either provided incremental information about a firm's cash tax payments or can better understand the performance information in pre-tax earnings by mapping TRI into book income. My tax anomaly results are generally stronger in the post-Schedule M-3 period, indicating that the book-tax difference detail in the Schedule M-3 is a particularly valuable information source for investors with access to it. Together, these results suggest that the Schedule M-3 is a particularly important source of TRI, as well as that TRI is more valuable when it is of higher quality.

In these and further analyses, I find that tax response coefficients are lower and that tax-related market anomalies are stronger prior to loan issuance, but only for institutional loans. These results are consistent with institutional investors identifying firms whose TRI is potentially most valuable ex-ante, and participating in loan syndicates to obtain this information. Finally, I also find evidence that suggests that 
the information transmitted by lenders is unique to taxes, and not a correlated piece of non-tax information.

This study provides valuable empirical evidence regarding the usefulness of TRI to equity investors and contributes to the policy debate over whether corporate TRI should be publicly disclosed (Lenter et al. 2003; Morris 2015). My findings that equity investors increase their reliance on tax information and trading efficiency following the receipt of TRI supports the pro-disclosure position, though I do not examine all costs and benefits of public tax return disclosure (see Section 2.1). Furthermore, my results around Schedule M-3 implementation suggest that the clearer, more-detailed information on book-tax differences in the Schedule M-3 may be a particularly useful tax return disclosure to provide investors. I also contribute to literature that examines the incremental value of tax information contained in financial statements relative to non-tax information (Hanlon et al. 2005; Koester 2011) by showing that TRI is useful to investors incremental to both non-tax and tax financial statement information. Although my results can only speak specifically to the incremental usefulness of the book-tax difference information on the Schedule M-3, tax returns also contain information about taxable income, taxes payable, and firm operations that may be useful to investors incremental to the information contained in financial statements (see Section 2.2).

Because I examine the usefulness of TRI in a syndicated loan setting, I also contribute to the literature on syndicated loans and information transmission by lenders (Dennis and Mullineaux 2000; Sufi 2007; Bushman et al. 2010; Ivashina and Sun 2011). Prior literature on information transmission by lenders either does not examine the source of the private information or identifies private, pre-announcement knowledge of large but rare corporate events (e.g., private-equity buyouts, loan origination and amendments) as the source (Acharya and Johnson 2010; Massoud et al. 2011). By identifying tax returns as a valuable source of private information that can be transmitted by lenders to equity investors, I document a routinely created source of private information that all firms produce. Additionally, my results suggest that TRI is an important determinant in institutional investors' decisions to participate in a loan syndicate.

This paper proceeds as follows: Section 2 summarizes my setting and related literature. Section 3 develops my primary hypothesis. I discuss my empirical design and data in Section 4, and my results in Section 5. Section 6 concludes. 


\section{Background and Related Literature}

\subsection{Public Disclosure of Tax Returns - Policy Background}

The debate over whether tax returns should be publicly disclosed has a long history. In 1909, when the corporate excise tax that would evolve into the current income tax system was enacted, excise tax returns were made open to public inspection for the purpose of making manipulation of corporate financial disclosures more apparent to investors (Kornhauser 2010). However, public disclosure of tax returns was limited in 1917 and further restricted in 1976 under public pressure over individual taxpayer privacy concerns (Morris 2015). ${ }^{6}$ Currently, Internal Revenue Code $\S 6103$ prohibits non-voluntary disclosure of tax returns except under limited circumstances. ${ }^{7}$

While U.S. corporate tax returns are currently protected from disclosure, the debate about whether these returns should be made public, in whole or part, continues. A major issue in this debate, and what I examine in this study, is whether tax returns would provide new information to investors or help them better process tax information they already have. However, there are other costs and benefits to tax return disclosure that are raised in this debate. Potential benefits of disclosure include helping non-tax government regulators better regulate corporations, increasing public awareness of tax policy and the debate over tax reform, and increasing corporate tax compliance among firms who could suffer consumer or supplier backlash (such as boycotting firms or reporting them to tax authorities with limited enforcement resources) due to having their tax non-compliance made public (Everson 2008; Bø et al. 2015; Morris 2015). Potential costs to tax return disclosure include providing proprietary corporate information to competitors, providing managers with motivation to manipulate taxable income to make it appear consistent with GAAP income, and, to the extent corporate tax return disclosure is limited to certain firms (e.g., those above a certain

\footnotetext{
${ }^{6}$ There were brief exceptions in 1924 and 1934 when tax returns were made public, although these laws were quickly repealed. The increased restrictions in 1976 were intended to limit access to tax returns within the government following allegations that President Richard Nixon had used TRI against his political opponents (Lenter et al. 2003).

${ }^{7}$ Examples of groups provided an exemption to access tax returns include state tax agencies, certain congressional committees, and specified law enforcement agencies, among others. $\$ 6103$ does not apply to the tax returns of U.S. not-for-profit entities (NFPs), whose tax filings are publicly available under IRC $\S 6104$. Because NFPs do not have shareholders, this setting cannot be used to examine the usefulness of TRI to investors.
} 
income threshold), leading to costly changes in corporate behavior to avoid tax return disclosure (Lenter et al. 2003; Morris 2015). ${ }^{8}$

However, there is little empirical evidence regarding any of the arguments in this debate. One exception is Hasegawa et al. (2013), who examine Japan, where some TRI was publicly disclosed from 1950 through 2004 for individuals and corporations whose income exceeded a certain threshold. Hasegawa et al. find that both individuals and corporations reported taxable income just below the reporting threshold more frequently than they reported taxable income just above the threshold, consistent with manipulation of taxable income to avoid public disclosure. Additionally, Bø et al. (2015) examine publicly available tax return disclosures of Norwegian business owners, and find that owners increase their reported taxable income after an increase in TRI accessibility. Finally, in a concurrent working paper, Hoopes et al. (2016) examine the recent disclosure of taxable income and taxes payable for large Australian corporations, and specifically whether companies manipulated their income to fall below disclosure thresholds and the consumer and investor reactions to the disclosure. ${ }^{9}$ They find that corporations manipulated their taxable income to fall below the taxable income reporting threshold and that consumer sentiment towards firms subject to disclosure declined. Additionally, they find that investors of firms subject to disclosure reacted negatively to both the implementation of the disclosure law and the disclosure event itself, although they note that the negative investor reaction to the TRI disclosure event could be due to a number of factors besides providing useful information to investors. Because the various explanations for an investor reaction to TRI disclosure cannot be identified in the Australian setting, Hoopes et al. only infer from the negative investor reaction that the Australian disclosure was considered costly by investors. Hoopes et al. also show

\footnotetext{
${ }^{8}$ Prior literature shows that firms are willing to manipulate taxable income to obscure earnings management even absent public tax return disclosure (Erickson et al. 2004). Additionally, since firms prefer to use earnings management strategies that do not affect taxable income (Badertscher et al. 2009), public tax return disclosure could reduce GAAP income manipulation as firms try to limit divergences in tax and GAAP numbers that could lead to detection of the earnings management.

${ }^{9}$ In December 2015, Australia began publicly disclosing the taxable income and taxes payable of Australian companies with taxable income of $\$ 100$ million (AUD) or more in an attempt to increase corporate transparency. News reports about the initial public disclosure note that the small effective tax rates of many major Australian companies led to an angry outcry from the Labor Party and trade unions, accusations of unethical tax practices, and concerns about the degree of verification of the disclosed information, which in turn led to calls for greater public education about corporate taxation from the Australian Treasurer (Evershed and Hurst 2015; Aston 2016).
} 
that investors of firms subject to disclosure negatively reacted to the implementation of the disclosure law two years prior to the disclosure of any TRI, suggesting that the investor reaction is not due to new information and that Australian investors were significantly able to predict the effect of TRI disclosure from available data sources. Thus, no prior study has identified whether tax returns are useful to equity investors.

While the U.S. setting is the focus of this study, the debate over whether TRI should be made public is not confined to the U.S., as Finland, Norway, and Sweden all currently require some disclosure of TRI, while Australia recently implemented the disclosure of some TRI (Hoopes et al. 2016). Additionally, in September 2016, the U.K. enacted a law to allow certain country-by-country tax reports to be made publicly available (Walker 2016). This debate also has implications for international relations. For example, the U.S. has indicated that it will refuse to share tax reporting data with countries that publicly disclose country-bycountry reporting data, which the European Commission has been considering and the U.K. recently moved towards doing (Ernst \& Young 2016).

These international settings may appear on the surface to offer the potential to empirically examine whether TRI is useful to equity investors. However, each setting is subject to a variety of data limitations and confounds that I summarize in Figure 1. Briefly, the primary issues with examining the usefulness of TRI to investors in these other settings include: (a) limited time series of data; (b) limitations on researcher access to data and the ability to match tax return data to investors; (c) disclosure thresholds that encourage manipulation of tax return data and result in significant differences on non-tax and non-disclosure dimensions between firms that do and do not disclose TRI; (d) disclosure of TRI at times of high sentiment regarding the corporate tax system, which can lead to behavioral biases in investor information use; and (e) widespread access to TRI, which can lead to changes in behavior by customers, suppliers, and lawmakers and make it unclear whether investor responses to tax return disclosures are due to the information content of the disclosure or anticipation of other parties' use of this information. These other settings also have unique regulatory, economic, legal, cultural, and reporting features that could limit the applicability of any inferences to settings outside of these countries, such as the U.S. These identification issues motivate the need for a setting where TRI is provided to only some sophisticated equity investors so as to not create 
changes in behavior among other corporate stakeholders or affective reactions among investors that could bias pricing judgments (Elliott et al. 2014).

\subsection{Tax Information}

Currently, investors have access to information about firms' cash flows, assets, liabilities, equity, changes in stockholder equity, and income as computed under GAAP in the primary financial statements and significant supplemental detail in the statement footnotes. The financial statements also contain significant detail on firms' tax positions. On the balance sheet, firms report current taxes payable or receivable, deferred tax liabilities or assets, and a liability for uncertain tax benefits. On the income statement, firms report current tax expense (the portion due to current-period activity) and deferred tax expense (the portion due to changes in deferred tax liabilities/assets). Required footnote disclosures include a reconciliation of the reported effective tax rate to the statutory tax rate, listing of material deferred tax liabilities and assets, reconciliation of the liability for uncertain tax benefits, the amount of tax loss and credit carryforwards, and the amount of foreign earnings protected from U.S. taxes on repatriation. ${ }^{10}$ Given all of this information available to investors without the tax return, opponents of tax return disclosure argue that investors would not find any additional, meaningful information in tax returns (Lenter et al. 2003; TEI 2006). However, commentators and academics continue to claim that it is nearly impossible to determine firms' taxable income and taxes payable from financial statements (Hanlon 2003; Mills and Plesko 2003; McGill and Outslay 2004; Donohoe et al. 2012).

So what specific information in a tax return might be valuable to investors? One major item is the tax-basis income statement included on page 1 of the U.S. corporate tax return (Form 1120). Not only does this page 1 provide an alternative measure of firm performance in the form of taxable income, but also an alternative measure of major pieces of firm performance such as sales, cost of goods sold, depreciation expense, and bad debt expense. This alternative measurement is valuable if there is noise in GAAP numbers that is not mirrored by tax accounting rules. Such noise could occur if (a) GAAP does not map well to

\footnotetext{
${ }^{10}$ See Accounting Standards Codification 740-10-50 and 740-30-50 for further detail.
} 
underlying economic fundamentals, (b) GAAP provides for estimation, such as estimation of fair values, that is subject to the risk of estimation errors, or (c) GAAP provides managers with discretion that they use to manipulate financial statements. As explicitly modeled by Blackburne and Blouin (2016) and Dhaliwal et al. (2017), the existence of noise in GAAP which is not duplicated in tax accounting will result in unique information about the underlying construct of interest (e.g., firm performance or asset depreciation) being found in tax accounting numbers. In other words, if tax accounting either provides more accurate measurement or limits manager manipulation of accruals, investors may be better able to understand and forecast firm performance when they have access to both GAAP financial statements and tax returns. While the bottom-line taxable income and taxes payable may be particularly important, given that they are subject to public disclosure in some jurisdictions for the purpose of increasing corporate transparency, any income or expense item that is particularly important for valuation purposes and/or provides considerable opportunities or incentives for earnings management (e.g., loan loss accruals; Liu et al. 1997) may be better understood by investors with access to the tax return.

However, the Form 1120 income statement is not the only source of TRI that may be valuable to investors. The Schedule M-3 reports detail on book-tax differences (BTDs) in significantly greater detail than financial statements, and could increase corporate transparency by providing a roadmap to understand firms' tax positions. The detailed BTDs in Schedule M-3 provide not only a detailed breakdown of book and taxable income, but also the nature (permanent vs. temporary) of any differences, which may aid investors in interpreting the growth, persistence, and risk attributable to a variety of firm activities. Schedule $\mathrm{L}$ in the Form 1120 provides a book-basis balance sheet, which should mirror the GAAP balance sheet; however, differences in GAAP and tax consolidation rules may result in a very different consolidated group for this Schedule, which may better inform investors about the nature of claims on firm assets. Additional tax return items/forms that may provide clearer and more detailed information than currently included in the financial statements are Form 5471, which reports detail on all foreign subsidiaries and their intercompany transactions (Collins and Shackelford 1998), Schedule D, which provides detail on a firms' capital gains and losses, and Form 4562, which provides detail on firms' depreciable assets, among many 
others. Since the detail in these items is difficult or impossible to determine from the financial statements, explicit tax return disclosure would be needed to accurately provide this information to investors.

An important difference between financial statements and tax returns, aside from different information content, is that tax returns are subject to different reporting deadlines than financial statements. Most public-company financial statements must be filed within 60 to 90 days of the fiscal year end; however, with extensions, corporate tax returns are not required to be filed until 9.5 months after the fiscal year end. This means that TRI from the filed tax return may be very stale by the time it can be provided to investors. However, even if a firm waits until the last day to file its tax return, it still must have had a reasonably accurate estimate of many major pieces of the tax return, including the tax-basis income statement and book-tax differences, in filing its tax return extension, which is due 3.5 months after the end of the fiscal year. Thus, even absent a formally-filed tax return, major pieces of TRI will be known by firms concurrent with filing the financial statements. If TRI is useful to equity investors, it is likely that a proforma tax return prepared for a filing extension will be just as useful. However, even if TRI is not transmitted to equity investors until after the filing of the tax return, the stale information provided may be useful to investors if it is information that they have not been able to obtain from other sources that has persistent information content. For example, if the 2016 tax return can reveal earnings management from the 2016 financial statements that will not reverse in 2017, then this TRI will still be timely even if not provided to investors until October 2017.

While there is no prior evidence regarding whether information in the tax return is useful to investors, a sizeable literature examines the information content of tax information provided in financial statements. For example, Hanlon et al. (2005) show that taxable income inferred from the financial statements is a useful metric of firm performance incremental to book income. Ayers et al. (2009) show that this effect is stronger when book income is lower quality and weaker when imputed taxable income likely contains more noise (i.e., when there is high tax planning). Imputed taxable income has also been shown to have information content incremental to book income for earnings growth (Kim et al. 2015), discount rate news (Henry 2014), and firm risk (Dhaliwal et al. 2017). 


\subsection{Market Efficiency with respect to Tax Information}

Prior literature has also identified financial-statement-derived tax metrics that have unique, valuerelevant information content that is incremental to book income, and finds that investors generally misprice this information. Lev and Nissim (2004) examine the ratio of imputed taxable income to book income and find that it predicts future earnings growth, but that investors do not fully price this information, leading to annual abnormal returns of up to 5.6 percent. Hanlon (2005) finds that firms with both large positive and large negative book-tax differences (BTDs) have lower earnings persistence. She also finds that the market appears to price the information in large positive BTDs, but not the information in large negative BTDs. ${ }^{11}$ Schmidt (2006) shows that the tax change component (TCC) of earnings predicts future earnings, particularly for the portion of the TCC that occurs after the first quarter of the year (i.e., the "revised" TCC). However, Schmidt also shows that investors underweight this information, resulting in annual abnormal returns of up to 4.9 percent. Finally, Thomas and Zhang (2011) find that tax expense surprises are associated with future changes in earnings and tax expense. Despite this predictable association, Thomas and Zhang find that the market does not react to this information until the future changes in earnings and tax expense are observed, resulting in a trading strategy with annual abnormal returns of up to 9 percent.

This literature also examines whether other market participants understand the information in these tax metrics, and yields mixed results. Analysts, like investors, struggle to understand and incorporate tax information into their forecasts (Plumlee 2003; Weber 2009; Kim et al. 2015). Credit rating agencies, though, do adjust their ratings in line with the information contained in BTDs (Crabtree and Maher 2009; Ayers et al. 2010). One reason why credit ratings agencies may use tax information more effectively than others is that they can receive private information under Regulation Fair Disclosure, and thus may be receiving TRI. However, it may also be that the information in financial statement tax accounts has different implications for debtholders and credit ratings agencies versus equityholders. ${ }^{12}$ Insiders and short sellers

\footnotetext{
${ }^{11}$ Incorporating BTD information into trading on the accrual anomaly provides annual abnormal returns of 4 percent. 12 Additionally, (a) this literature has not examined whether credit ratings agencies fully use the tax information they have (i.e., whether current tax information predicts future credit rating changes or predicts default incremental to credit ratings), (b) the discrete nature of credit ratings may hide ineffective tax information use that continuous returns and
} 
also trade on mispricing related to the ratio of taxable income to book income, suggesting that they understand and use the information in the financial statement tax accounts, although they do not fully arbitrage away mispricing (Chi et al. 2014).

Other studies have examined these tax-related market anomalies in greater detail. Chi et al. (2014) find that the Lev and Nissim (2004) anomaly continues to exist after controlling for other tax anomalies and additional controls. Hepfer (2016) finds that the Lev and Nissim (2004) and Hanlon (2005) anomalies continue to exist after controlling for the Fama and French (2015) five factors; however, he also finds that these tax anomalies are subsumed in his sample by the non-tax-related value-glamor anomaly. ${ }^{13}$ Finally, Kerr (2016) uses a cross-country setting to examine the Thomas and Zhang (2011) anomaly and shows that it exists outside the U.S and that it is stronger when tax enforcement is higher (i.e., where there is likely to be greater verification of tax amounts by tax authorities).

Overall, this literature shows that investors are not fully incorporating the tax information they have into their valuation judgments. Given that market anomalies can have real effects on firms and lead to significant value losses (van Binsbergen and Opp 2016), it is important to consider how to alleviate these tax-related market anomalies. It is possible that managers could try to provide better tax information, either through real actions, such as stock repurchases or repatriations, or through better mandatory (e.g., financial statements) or voluntary disclosure (e.g., management forecasts). However, managers may also not be willing to provide information through these channels as they can be very costly (Botosan and Stanford 2005; Foley et al. 2007; Beyer et al. 2010). Another way to alleviate these tax anomalies may be to provide investors with some TRI, as suggested by both proponents of public tax return disclosure and some of the studies in this literature (e.g., Hanlon 2005 and Chi et al. 2014).

analyst forecasts reveal, and (c) given the severe consequences of credit rating agency failure, credit rating agencies may simply analyze the financial statements more thoroughly or provide their raters the resources and training necessary to better analyze the tax information in financial statements. For these reasons, it is unclear whether any TRI that credit ratings agencies receive is useful to them, much less to equity investors.

${ }^{13}$ Because both BTD-related anomalies (Lev and Nissim 2004) and the value-glamour anomaly (Desai et al. 2004) represent some degree of mispriced growth, these results suggest that there is not unique information in BTDs that can be obtained from tax sources. I control for the value-glamour anomaly in my analyses, since I am interested in tax-relevant information that is incremental to publicly-available information. 


\subsection{Syndicated Loans and Information Transmission to Equity Markets}

To operationalize my study of the usefulness of TRI to equity investors, I rely on features of the syndicated loan market. The syndicated loan market has become a significant source of capital for firms in recent years, vastly outpacing public bond and equity markets with new issuances of $\$ 4.7$ trillion globally in 2014 alone (Thompson Reuters 2014). Syndicated loans can be thought of as a hybrid between public bonds and private bank loans (or transaction and relationship loans), and entail multiple lenders jointly entering into a direct lending arrangement with a borrower (Dennis and Mullineaux 2000; Sufi 2007).

A typical syndicated loan begins with a borrower approaching a single lender about obtaining a certain amount of financing for a specified purpose. This lender (the "lead arranger") then agrees to provide the funds subject to certain fees, interest rates, covenants, and collateral (Sufi 2007). ${ }^{14}$ The loan agreement will either be committed to up-front by the lender or will be conditional on the lender obtaining a certain amount of financing from other lenders (i.e., building a sufficiently-large syndicate). The lead arranger will then seek out additional lenders to participate in the lending syndicate, often providing prospective syndicate members with detailed information about the borrower in a confidential information memo (Dennis and Mullineaux 2000). ${ }^{15}$

Once the syndicate is established, the lead arranger continues to serve in an administrative and coordination role by, among other duties, handling the calculation of interest payments, holding collateral, and enforcing debt covenants (Dennis and Mullineaux 2000; Bushman and Wittenberg-Moerman 2012). For these services, the lead arranger typically earns a fee of up to 175 basis points of the loan amount (Sufi 2007). While the lead arranger is the primary point-of-contact between the syndicate and the borrower, all syndicate-member lenders have a direct relationship with the borrower (Gorton and Pennacchi 1995).

\footnotetext{
${ }^{14}$ While any lender can be a lead arranger, over 55 percent of DealScan lenders have never been a lead arranger. Lead arrangers are frequently large financial institutions; for example, Bank of America is the most common lead arranger, serving in that role for over 9 percent of DealScan loans.

${ }^{15}$ Because the lead arranger typically selects the participants in a loan syndicate, the borrower may not have much or any control over whether an institutional investor is included in the loan syndicate. Further, because prospective lenders that do not eventually become part of the loan syndicate can obtain confidential information about a firm, potentially including TRI, a loan targeted towards institutional investors may have more institutional investors with access to some confidential TRI than just those in the syndicate.
} 
While many of the lenders that participate in loan syndicates are banks, a sizable and growing portion of loan syndicate participants are institutional investors, such as hedge funds, mutual funds, insurance firms, and pensions (Taylor and Sansone 2007; Ivashina and Sun 2011). ${ }^{16}$ These investors (as well as banks with non-lending operations) are generally required to institute policies (frequently called "Chinese Walls") to prevent the transmission of private information that was obtained in their role as lenders to other parts of their business (e.g., to equity investing and analyst operations) (Chen and Martin 2011). ${ }^{17}$

However, prior literature has shown that these policies are frequently ineffective, as private information given to lenders is frequently transmitted to non-lender parties. For example, Chen and Martin (2011) find that bank-affiliated analysts' forecast accuracy increases when their affiliated bank issues a loan to firms they follow, consistent with the transmission of private information between a lender's operating units. Ivashina et al. (2009) document that firms are more likely to become takeover targets of an acquirer when both the target and acquirer have a borrowing relationship with the same bank, consistent with banks transmitting private information to potential acquirers. Cheng et al. (2016) show that audit quality improves for firms following (a) their auditor starting to audit a bank they borrow from or (b) firms obtaining a loan from a bank audited by their own auditor, suggesting that banks may transmit information to auditors.

Private information given to lenders is also transmitted to equity investors. Institutional investors earn significant abnormal returns from trading in the stock of firms for whom they also act as a lender in a lending syndicate following loan information events (Ivashina and Sun 2011). There is also a significant increase in equity short-selling prior to loan origination announcements when hedge funds are part of the lending syndicate, and hedge funds participate in lending syndicates primarily for firms with lower credit quality where private information offers more valuable trading opportunities (Massoud et al. 2011).

\footnotetext{
${ }^{16}$ Jiang et al. (2010) suggest that one reason for this increase in institutions that hold both debt and equity of a firm is that it can reduce creditor-shareholder conflicts. They find that syndicated loans that have a participant who also holds some of the borrower's equities have lower credit yield spreads, likely due to reduced creditor-shareholder conflicts.

${ }^{17}$ While Regulation Fair Disclosure (Reg. FD, implemented in 2000) limits the ability of firms to provide information to other parties unless it is concurrently released to the public, lenders can continue to receive private information from borrowers without the public disclosure of such information by signing a confidentiality agreement with respect to the non-public information they receive (Li et al. 2015).
} 
Bushman et al. (2010) document that information is incorporated into stock prices faster when information is also incorporated into secondary loan market prices faster. However, they only find these results when institutional investors are part of the loan syndicate, consistent with institutional investors using information gained from their role as a lender to trade in firms' equities. Finally, unusually large trading volume and price swings preceding private-equity buyouts are associated with both more equity-holders and more syndicated loan participants, consistent with transmission of and trading on inside information (Acharya and Johnson 2010).

How the private information given to lenders is transmitted to equity markets and other non-lender parties is unclear. However, prior literature discusses three possible channels. First, it is possible that institutional investors directly trade in equity markets based on private information they received in their role as lenders, in violation of SEC insider trading rules (Ivashina and Sun 2011). ${ }^{18}$ Second, institutional investors may provide their affiliated equity analysts with the private information they received as lenders, in violation of Regulation Fair Disclosure (Chen and Martin 2011). If these analysts then use the information to make forecasts that are used by equity investors, the private information will be incorporated into equity prices. Finally, institutional investors may simply be more aware of the information content in secondary loan markets where insider trading is not illegal. By weighting the publicly-available movements in secondary loan market prices and volume higher in their equity-investment decisions, institutional investors may effectively incorporate private information in a legal manner (Bushman et al. 2010; Addoum and Murfin 2016). ${ }^{19}$ Thus, for the information transmission to equity markets to be legal, the loan must be traded on a secondary loan market.

What specific private information is transmitted is not entirely clear from prior literature. Some of

\footnotetext{
${ }^{18}$ Ivashina and Sun (2011) describe anecdotes involving Movie Gallery and Delphi Corporation where institutional investors were accused of equity trading on insider information obtained in their role as syndicate lenders.

${ }^{19}$ Addoum and Murfin (2016) show that an equity trading strategy that mirrors publicly-available price movements in secondary loan markets can earn excess returns of 1.4 to 2.2 percent per month. They also find that this trading strategy only works for stocks that are not held by mutual funds that also participate in syndicated loan markets, consistent with these institutional investors recognizing and trading in equities on the information inherent in secondary loan market prices (or the private information that is also incorporated into secondary loan market prices).
} 
this literature suggests a specific information event, such as the issuance of a loan, loan term amendments, or a private-equity buyout; however, the pervasive and long-term nature of abnormal trading returns suggest that there may also be more regular and fundamental information that is transmitted. One source of information that is available to lenders, but not to equity markets, is firms' tax returns. Recent research documents that lenders frequently request access to borrowers' tax returns, both ex-ante for due diligence purposes and ex-post for continual monitoring (Lisowsky et al. 2017; Minnis and Sutherland 2017). ${ }^{20}$ Indeed, tax returns are the most frequently requested source of data besides financial statements, and financial statements and tax returns act as complements when information asymmetry is greater.

\section{Hypothesis Development}

Opponents of tax return disclosure argue several reasons that tax returns will not be useful to equity investors. First, tax returns may not provide any additional useful information beyond what equity investors can obtain from analysts, credit rating agencies, media reports, social media, company websites, voluntary management disclosures, and financial statements (Morris 2015). Financial statements in particular already contain significant detail about companies' tax accounts (Plesko 2003; Frischmann et al. 2008; Raedy et al. 2011). Second, tax returns are not designed for market participants. Where financial reporting is explicitly designed to provide reliable, decision-relevant information to corporate stakeholders (FASB 1978), tax reporting is designed to raise revenues for the government in an efficient and equitable manner (Manzon and Plesko 2002) and is frequently used to enact governmental policies and subsidies (e.g., tax credits for certain green-energy investments). ${ }^{21}$ Finally, even if tax returns contain incremental useful information, their length and complexity could lead to misinterpretation that could reduce market efficiency with respect

\footnotetext{
${ }^{20}$ Discussions with a former employee of a major financial institution whose role was to oversee informationtransmission policies for the institution's syndicated loans suggest that (a) the institution almost always requested the borrower's entire corporate tax return as filed and (b) that as many as 10,000 unique individuals might have access to the tax return for large syndicated loans.

${ }^{21}$ The use of tax reporting to implement non-tax policies and subsidies adds noise to tax return numbers both by itself and by providing incentives for firms to manipulate taxable income across time, jurisdictions, and tax classifications (e.g., capital vs. ordinary income) to take advantage of these rules (Scholes et al. 1992; Lester 2015; Demeré and Gramlich 2017).
} 
to taxes. ${ }^{22}$ These arguments are supported by evidence in prior literature that investors and sophisticated market participants, such as analysts, do not even fully understand the tax information that is provided for investors' benefit in the financial statements (Lev and Nissim 2004; Schmidt 2006; Weber 2009; Thomas and Zhang 2011; Kim et al. 2015).

On the other hand, proponents of public tax return disclosure argue several reasons that tax returns would be very useful to equity investors. First, tax returns contain detailed information that is not included in the financial statements, yet could be important to investors' decision-making; Schedule M-3 is a prime example (Donohoe and McGill 2011). ${ }^{23}$ Second, tax returns offer an alternative measurement of firm performance. As discussed in Section 2.2, TRI can provide additional information about the measurement quality of financial statements (and thus firm performance and risk) if measurement error in tax return amounts is uncorrelated with the measurement error in financial statement amounts (Blackburne and Blouin 2016; Dhaliwal et al. 2017).

However, even if tax returns do not convey additional decision-relevant information to investors, providing investors with tax returns could still help investors better use the tax information they have from other available sources. Since it can be very difficult to piece together a firm's tax position from the financial statements (Hanlon 2003; McGill and Outslay 2004) and can require difficult and complex calculations (Graham 1996), providing investors with the same tax information that is currently included in the financial statements in an easier-to-process manner (i.e., saliently and without requiring significant computations), such as by directly giving them the tax return, may be beneficial. Prior literature has shown that simply changing the presentation of information to make it easier to process can enhance information

\footnotetext{
${ }^{22}$ The Tax Executives Institute suggests that without significant training in tax law and complex business transactions, as well as access to tax-subject-matter specialists and companies' detailed tax records, investors will "likely misunderstand and misconstrue" TRI (TEI 2006, 242). Additionally, former Treasury Secretary Paul O'Neill has said that making tax returns public could subject companies to "misinformed, inexpert analysis" (Lenter et al. 2003, 806). Since easier processing of less value-relevant information can lead investors to inefficiently overweight the information (Elliott et al. 2015), providing non-value-relevant TRI to equity investors could result in less market efficiency due to investor overweighting of this information.

${ }^{23}$ In addition to providing more information than financial statements on these items, tax returns have the additional benefit of being highly quantitative (i.e., versus potentially-qualitative financial statement disclosures), which can enhance information flow and user processing (Lundholm et al. 2014; Hutchens 2015).
} 
acquisition (Hirst and Hopkins 1998) and improve investor weighting of information (Maines and McDaniel 2000), leading to greater market efficiency (Dietrich et al. 2001; Elliott et al. 2015). This effect occurs because investors have limited attention, and thus are less likely to incorporate information into their judgments when it is more difficult to process (Bloomfield 2002; Hirshleifer and Teoh 2003).

Given these competing arguments, it is an empirical question whether TRI is useful to equity investors. At the conceptual level, my hypothesis is stated in the null as:

Hypothesis (Conceptual): Tax return information is not useful to equity investors.

To operationalize this conceptual hypothesis, I rely on features of the lending environment described in Section 2.4. In evaluating and monitoring borrowers, lenders frequently request access to borrowers' tax returns (Lisowsky et al. 2017; Minnis and Sutherland 2017). Additionally, private information conveyed to lenders is frequently transmitted to equity markets when institutional investors are part of the lending syndicate (Bushman et al. 2010; Ivashina and Sun 2011; Massoud et al. 2011). If investors find the TRI transmitted to them by institutional investor-lenders useful, then they should change their valuation of tax expense, with an increase (decrease) in the valuation suggesting that TRI is providing additional information about firm performance (cash taxes paid) (See Appendix A). Additionally, the transmission of TRI to equity investors should reduce tax-related market anomalies if TRI is valuable to them. I state my operational-level hypothesis in the null as:

Hypothesis (Operational): Tax expense valuation and market efficiency with regards to tax information does not change when institutional lenders are involved in a loan syndicate.

\section{Empirical Design and Data}

\subsection{Empirical Design}

To test my hypothesis, I adapt prior models of taxable income valuation (e.g., Hanlon et al. 2005; Thomas and Zhang 2014) to a difference-in-differences specification. ${ }^{24}$ This model enables me to examine

\footnotetext{
${ }^{24}$ Previous literature contrasts imputed taxable income versus book income, rather than pre-tax income and tax expense. However, because imputed taxable income is simply a constant transformation of deferred tax expense or total tax expense, my design should not matter except to remove unnecessary noise from mismeasurement of firms' tax rates. I focus on total tax expense to avoid issues with simply using deferred tax expense and because my sample
} 
whether tax expense has informational value to investors, in that a change in tax expense valuation following the receipt of TRI from institutional syndicated loans implies the arrival of new information. Additionally, this model allows me to directly compare how information about pre-tax income and tax expense changes relative to each other. This is important because I do not directly observe the transmission or nature of TRI, and thus I can differentiate whether the information I capture is tax-specific or simply taxcorrelated information about pre-tax performance by seeing whether the coefficients on pre-tax income and tax expense act similarly, which would suggest that I may be capturing a non-tax omitted performance factor, or change in unique ways to each other, which would suggest that the information investors are receiving is uniquely tax-related. Finally, this model reveals the type of information conveyed by TRI (Shevlin 2002; Hanlon et al. 2005).

In general, these models have many moving parts, making interpretation of coefficients difficult alone (Thomas and Zhang 2014), much less in a difference-in-differences framework. I discuss the interpretation of these models in Appendix A. Briefly, I expect that a positive change in tax expense valuation (i.e., the difference-in-differences coefficient) indicates that investors receive access to either more tax-related performance information or more information about potential sources of noise in the ability of tax expense to map to cash tax payments. I expect that a negative change in tax expense valuation indicates that investors receive access to either more information that helps them map tax-related performance information into pre-tax performance (i.e., tax information that maps to and confirms information about pre-tax income) or more information about current or future cash tax payments.

Specifically, I estimate using OLS regression for firm $i$ at time $t$ :

$$
\begin{aligned}
& \operatorname{RRET}_{i t}=\beta_{0}+\beta_{1} P T I_{i t}+\beta_{2} T E_{i t}+\beta_{3} P O S T_{i t}+\beta_{4} I N S T_{i t}+\beta_{5} P O S T \times I N S T_{i t}+\beta_{6} P O S T \times \\
& T E_{i t}+\beta_{7} I N S T \times T E_{i t}+\beta_{8} P O S T \times I N S T \times T E_{i t}+\sum_{j=9}^{J} \beta_{j} C T R L_{j i t}+\epsilon_{i t},
\end{aligned}
$$

where the dependent variable is the annual buy-and-hold return (RRET), measured from the end of the third

consists of treatment and control firms that experience similar corporate events, making it superior to focusing solely on deferred tax expense (Gao et al. 2015). 
month of the current fiscal year. ${ }^{25}$ While a typical earnings-response regression will have post-tax earnings as the primary independent variable, here I split earnings into pre-tax earnings $(P T I)$ and tax expense $(T E) .{ }^{26}$ All variables are further defined in Appendix B.

To implement the difference-in-differences design, I include POST and INST, as well as their fullycrossed interactions with TE. POST is equal to one for the year of a loan issuance and the following two years, and zero for the three years preceding the issuance of a loan. ${ }^{27}$ INST is equal to one for firms receiving a syndicated loan designed for institutional investors, and zero for firms receiving a non-institutional syndicated loan. More specifically, I consider a loan as designed for institutional investors if it is designed to be traded on a secondary loan market. This matches how prior literature has proxied for institutional loan ownership (Bushman et al. 2010; Bushman and Wittenberg-Moerman 2012) and allows me to concentrate on loans where legal transmission of information is possible (e.g., Section 2.4). Because both treatment $(I N S T=1)$ and control $(I N S T=0)$ firms issue syndicated loans, this design controls for self-selection effects related to the choice to obtain financing through a syndicated loan. Absent the difference-in-differences design (i.e., interactions with INST and POST), the coefficients on PTI and TE could be interpreted as the extent to which returns respond to pre-tax earnings or tax expense, respectively. In the difference-indifferences design (i.e., interacting TE with INST and POST), the coefficient on TE represents the valuation of tax expense in the pre-loan period for firms that obtain a non-institutional loan, and this coefficient acts as a baseline in that all coefficients on $T E$ interactions represent deviations from this valuation. The

\footnotetext{
${ }^{25}$ I measure returns with a three-month delay to enable time for the prior-year Form 10-K to be filed and to ensure my return window includes the current-year Form 10-K. All inferences remain the same if I measure the returns from the end of the fourth month following the fiscal year end. I incorporate delisting returns per Beaver et al. (2007).

${ }^{26} \mathrm{In}$ common earnings response coefficient regressions, returns are regressed on the change in earnings, rather than the level of earnings (Kothari 2001). However, I regress returns on the levels of pre-tax earnings and tax expense to ensure a match of the returns and earnings variables as total annual flows and avoid making assumptions about expected earnings and tax expense. To address concerns about correlated omitted variables, I add firm fixed effects (Kothari 2001; Wooldridge 2010). Firm fixed effects also remove some bias in returns due to market inefficiencies (see Section 5.3) and capture earnings and tax expense expectations in a more robust manner than first-differencing the independent variables. Nevertheless, I also report regressions in which I replace TE and PTI with their first differences scaled by the market value of equity (i.e., $\triangle T E$ and $\triangle P T I$ ). As shown in Table 2, Panel $\mathrm{D}$, results from these tests are similar or stronger than the results I report, supporting all my inferences.

${ }^{27}$ I limit the sample to firm-years within three years of a loan issuance and eliminate observations that lie within both a pre-issuance and post-issuance three-year window. Inferences remain the same if I narrow the window to two years or eliminate the loan issuance year and make the post period the three years following the year of the loan issuance.
} 
coefficients on $I N S T \times T E$ and $P O S T \times T E$ then represent the difference in tax expense valuation from the baseline for the pre-loan period of institutional loan borrowers and the post-loan period of non-institutional borrowers, respectively. Here the primary coefficient of interest is $\beta_{8}$ (on $I N S T \times P O S T \times T E$ ), which captures the differential valuation of tax expense that is unique to the post-loan period of institutional loan borrowers whose equity investors likely receive TRI. If the transmission of TRI to equity markets increases (decreases) investor valuation of tax expense, I would expect a positive (negative) $\beta_{8}$.

In addition to my primary variables, I control for the degree of firms' institutional ownership $(I O P C T)$. Because my treatment variable captures whether institutional investors can be part of the loan syndicate, it is possible that INST could capture the extent of institutional equity ownership, and thus could simply represent greater overall investor sophistication or better corporate governance rather than TRI transmission to equity markets. By explicitly controlling for the degree of institutional ownership, I control for these alternate explanations. ${ }^{28}$

While taxable income valuation models are typically estimated with few control variables, I also include a vector of controls $(C T R L)$ that could have implications for my setting in some specifications. I control for the logarithm of the market value of equity ( $L M V E)$, the book-to-market ratio (BTM), market beta $(B E T A)$, stock return volatility $(R V O L)$, special items $(S P I)$, and net operating loss carryforwards $(N O L)$ to ensure that my results are not driven by differences in size, risk, growth, one-off earnings items, or tax carryforwards..$^{29} \mathrm{I}$ also control for a firm's analyst following (ANCOV). Since the receipt of a loan could also result in changes in analyst following, particularly if a lender also has equity analysts with a preference for following the bank's borrowers, controlling for analyst following helps to ensure that my

\footnotetext{
${ }^{28}$ Because not all institutional owners may be equally sophisticated or effective at governance, in untabulated analyses I replace $I O P C T$ with (a) the percentage ownership of large blockholders (i.e., institutions owning $>5 \%$ of a company's stock) or (b) the percentage ownership of activist institutions (defined per Cremers and Nair (2005) and Larcker et al. (2007)). Controlling for these alternative variables does not quantitatively affect my results.

${ }^{29}$ Net operating loss (NOL) carryforwards represent a significant source of noise in matching book income to cash tax flows, and thus firms with NOL carryforwards may drive higher coefficients on $T E$. To further ensure that this is not driving my results, I repeat my analyses after dropping firms with NOL carryforwards. All inferences are unaffected, and the coefficient on $I N S T \times P O S T \times T E$ is actually larger after this change, supporting that information about firm performance, and not information about noise in tax expense matching, is behind my results.
} 
results are robust to changes in the information environment. To ensure that my results are incremental to features of the loan, I control for whether the loan is issued by an industry-specialist lender (ISPEC), whether the purpose of the loan is to engage in a restructuring or a merger/acquisition (REST), and whether the loan is secured $(S E C D)$, as well as the interaction of these variables with $P O S T .{ }^{30}$ Finally, I control for year and firm fixed effects.

While these regressions can help identify whether investors change their valuation of tax expense following the receipt of TRI, as well as the type of information investors are reacting to, these models cannot identify the optimality of investor reactions. Put another way, these models cannot determine whether investor reactions to TRI lead to more or less efficient market valuations. To examine whether TRI helps investors more efficiently value a firm and price its equity, I also examine prior models of tax-related market anomalies (e.g., Lev and Nissim 2004; Thomas and Zhang 2011) adapted to a difference-indifferences specification. Examining these anomalies is important given suggestions that providing investors with tax returns could lead to greater mispricing of tax information (TEI 2006). This test also provides a different way of examining whether investor valuations change in response to TRI, thus providing evidence to confirm or contradict results from Eq. (1). ${ }^{31}$

Specifically, I estimate using OLS regression for firm $i$ at time $t$ :

$$
\begin{aligned}
& \text { FFRET }_{i t+1}=\delta_{0}+\delta_{1} \text { POST }_{i t}+\delta_{2} I N S T_{i t}+\delta_{3} T A X_{i t}+\delta_{4} P O S T \times I N S T_{i t}+\delta_{5} P O S T \times \\
& T A X_{i t}+\delta_{6} I N S T \times T A X_{i t}+\delta_{7} P O S T \times I N S T \times T A X_{i t}+\sum_{j=8}^{J} \delta_{j} C T R L 2_{j i t}+\epsilon_{i t},
\end{aligned}
$$

where the dependent variable is the abnormal annual return from the Fama and French (2015) five-factor model (FFRET), measured from the end of the third month following the fiscal year end. ${ }^{32}$ The variable

\footnotetext{
${ }^{30}$ Because firms with industry-specialist lenders, restructurings, and secured loans may vary from other firms both prior to (i.e., a selection effect) and after the issuance of a loan, I construct these variables by assigning the value of the variable in the year of the loan issuance to the prior three years and the following two years, and then interact these variables with POST to allow for both an ex-ante effect and an ex-post effect to influence returns.

${ }^{31}$ While both Eq. (1) and Eq. (2) provide evidence regarding whether investors change their valuations in response to TRI, Eq. (1) is incrementally useful to examine over Eq. (2) as it can reveal what type of information investors are reacting to and can directly contrast tax-related information with information related to pre-tax income.

${ }^{32}$ All results are similar when using (a) annual market-adjusted returns as an alternative measure of abnormal returns or (b) using raw returns and separately controlling for the Fama-French five factors. I incorporate delisting returns
} 
$T A X$ is alternately one of six financial-statement-based tax metrics associated with anomalies, coded to yield a positive relation with FFRET; specifically, I use the ratio of taxable income to book income (TIBI; Lev and Nissim 2004), the annual tax surprise (TSUR; Thomas and Zhang 2011), the tax change component of earnings (TCCE; Schmidt 2006), the revised tax change component of earnings (RTCC; Schmidt 2006), and both negative and positive BTDs (NBTD and PBTD; Hanlon 2005). Absent the difference-indifferences design (i.e., interactions with INST and POST), the coefficient on TAX could be interpreted as the extent to which trading on tax information leads to abnormal returns (i.e., tax-related mispricing).

As in Eq. (1), I include POST and INST (as defined above and in Appendix B), as well as their fully-crossed interactions with $T A X$, to implement the difference-in-differences design. This means that the coefficient on TAX represents the abnormal returns predicted by the relevant tax anomaly variable in the pre-loan period for firms that obtain a non-institutional loan. This coefficient acts as a baseline in that all coefficients on $T A X$ interactions represent deviations from this level of mispricing. The coefficients on $I N S T \times T A X$ and $P O S T \times T A X$ represent the difference in tax anomaly mispricing from the baseline for the pre-loan period of institutional loan borrowers and the post-loan period of non-institutional borrowers, respectively. In this analysis, the coefficient of interest is $\delta_{7}$ (on $I N S T \times P O S T \times T A X$ ), which captures the differential mispricing of tax anomalies that is unique to the post-loan period of institutional loan borrowers when equity investors likely receive TRI. If the transmission of TRI to equity markets increases (decreases) market efficiency with respect to taxes, I would expect a negative (positive) $\delta_{7}$ since I code all $T A X$ variables to positively associate with abnormal anomaly returns.

I also include a vector of control variables (CTRL2) that have been shown to be important in evaluating tax-related market anomalies. To begin, I include the full CTRL vector from Eq. (1). Consistent with prior literature on tax anomalies (Thomas and Zhang 2011), I also control for earnings surprises $(E S U R)$, sales surprises (SSUR), and selling, general, and administrative surprises (GASUR). To ensure that my results are incremental to non-tax anomalies that may overlap with tax-related anomalies, I control for

according to Beaver et al. (2007). All inferences remain the same if I measure the returns from the end of the fourth month following the fiscal year end. 
the earnings-price ratio $(E P R)$, the ratio of operating cash flows to price $(C F P R)$, and pre-tax accruals (PTACC) (Desai et al. 2004; Hepfer 2016). I also control for net external financing (DXFIN), as it has been shown to be associated with future abnormal stock returns and I examine a setting where significant corporate financing activities (i.e., obtaining syndicated loans) are occurring (Bradshaw et al. 2006). ${ }^{33}$ Additionally, I control for year and two-digit NAICS industry fixed effects. Finally, to ensure that my results are not driven by selection bias due to the lead-arranger banks choosing whether to include institutional investors in the loan syndicate, I entropy balance observations with INST equal to one and observations with INST equal to zero across all control variables (Hainmueller 2012). ${ }^{34}$

\subsection{Data and Sample Selection}

To construct my dataset, I begin with the full universe of DealScan data from 1983 to 2012, since DealScan-Compustat link files only extend until $2012 .{ }^{35}$ I then eliminate loan facilities which are not syndicated loans, are not U.S. loans, or are not denominated in U.S. dollars. I next require a match with both Compustat and CRSP, and eliminate firm-years in the financial and utility industries (consistent with prior literature, e.g., Lev and Nissim 2004; Hanlon et al. 2005), with a non-U.S. incorporation code, and not within a six-year window of a loan issuance (i.e., $t-3$ to $t+2$ ). This leaves me with 41,518 firm-years. Further requiring that data be matched to the Thompson Reuters 13-F database leaves me with a full sample of 26,472 firm-years from 1980 to $2014 .^{36}$

\footnotetext{
${ }^{33}$ I omit controlling for the size of the loan issuance because DXFIN already captures changes in firm debt, though additionally controlling for the loan issuance size does not significantly affect any of my results.

${ }^{34}$ Entropy balancing is a relatively new technique to aid in calculating treatment effects that is similar to propensity score matching. Briefly, entropy balancing works by solving an optimization problem to create observation-byobservation weights that can then be applied using weighted least squares. The optimization problem is to find weights for each observation that are as close to one (the OLS weight) while also ensuring that treatment and control samples are balanced across covariates on the first and second moment (i.e., that treatment and control samples have similar means and variances for all control variables). To the extent that lead arrangers choose whether to issue a loan that can be traded on the secondary loan market based on the firm and loan characteristics I control for, this technique addresses possible selection bias (Hainmueller 2012).

${ }^{35}$ Ending my loan sample at 2012 means that I use Compustat data through 2014 and CRSP data through 2015 in my difference-in-differences design. The link file used is an extended version of the one compiled by Chava and Roberts (2008). I also test and find that all of my results hold in the post-SFAS 109 period (1993 and thereafter), as SFAS 109 represented a significant change in tax reporting in financial statements.

${ }^{36}$ I impose this constraint as my theory relies on the existence of institutional owners that trade in a firm's stock based on TRI. Replacing IOPCT with 0 for all unmatched observations does not affect my results and inferences. However, I do find that all my results are weaker or nonexistent among firms without institutional equity ownership, which
} 


\section{Results}

\subsection{Univariate Statistics}

Table 1, Panel A reports descriptive statistics for all variables. Approximately 21 percent of my syndicated loan observations are institutional loans (INST), with the remainder of the observations linked to non-institutional loans. Consistent with data availability becoming greater over time, approximately 64 percent of observations occur in the post-issuance period (POST) rather than the pre-issuance period. My sample observations also have significant institutional ownership (IOPCT), with institutional owners holding approximately 36 percent of the firm's shares for the average observation. Means and medians of these variables are similar to those in prior studies (e.g., Schmidt 2006; Chi et al. 2014; Baik et al. 2016). ${ }^{37}$

Table 1, Panel B reports tests of differences in means between non-institutional and institutional loans (columns 1-4) and between pre-issuance and post-issuance observations (columns 5-8). Because my hypotheses revolve around the relationship between various tax and return variables, this table does not provide any clear univariate evidence regarding my hypothesis. However, this table does reveal significant differences in many of the tax and control variables across both loan type and period. These differences suggest that sample selection bias due to covariate differences could be an issue, which motivates the use of entropy balancing to eliminate any bias due to covariate differences.

\subsection{Tax Expense Valuation Analyses}

I report the tests of Eq. (1) in Table 2. In Panel A, I illustrate how the coefficient on TE changes for firms before and after the issuance of a syndicated loan and between institutional and non-institutional loans. Consistent with prior literature (e.g., Hanlon et al. 2005; Ayers et al. 2009), the coefficient is significantly positive in three of the four cells, consistent with the proxy-for-profitability role of tax expense

suggests that firms who dual-hold equities and syndicated loans are the force that transmits TRI to equity markets in my setting (Addoum and Murfin 2016)

${ }^{37}$ One exception is $B E T A$, since prior literature typically uses the coefficient on the market return less the risk free rate alone, rather than incremental to the other four Fama-French (2015) factors, as I do to limit noise. Given that my controls contain proxies for other Fama-French factors, this distinction makes no difference in empirical tests. The large negative abnormal returns calculated using the Fama-French factors (i.e., FFRET) are consistent with prior literature (e.g., Baik et al. 2016), and large negative averages should be absorbed by the intercept in my regressions. 
dominating the matching role (see Appendix A). Interestingly, the one cell that is an exception is for firms in the pre-loan period who receive an institutional loan. This result is consistent with institutional investors being able to identify firms ex-ante with little publicly-available tax-related performance information, and choosing to participate in syndicated loans in part to obtain tax-related performance information from private sources, such as the tax return. However, none of the differences across these cells is statistically significant, nor is the $I N S T \times P O S T \times T E$ coefficient reported in the bottom-right cell significant, which means I cannot reject the null hypothesis that TRI is not useful to equity investors from this analysis. ${ }^{38}$

As is, these results suggest that TRI is not incrementally valuable to investors. However, it is possible that treating all observations the same is obscuring important variation in these results. Ayers et al. (2009) document that the information content of imputed taxable income is significantly stronger for firms with noisier book income. As such, I split my sample into firms with high and low discretionary accruals $(H I D A)$, and present these results in Panels B and C, respectively. ${ }^{39}$

For firms with high discretionary accruals in Panel B, I again find that three out of four $T E$ coefficients are statistically positive; however, here the $T E$ coefficient for firms in the pre-loan period who receive an institutional loan is statistically negative. Again, this result is consistent with institutional investors being able to identify firms ex-ante with little publicly-available tax-related performance information, and choosing to participate in syndicated loans in part to obtain tax-related performance information from the tax return. As opposed to the entire sample, though, there is a significant difference in the $T E$ coefficient for firms in the post-loan period who receive institutional loans (i.e., firms with likely transmission of TRI to equity markets), both relative to these same firms in the pre-loan period and overall,

\footnotetext{
${ }^{38}$ This insignificant result on $I N S T \times P O S T \times T E$ could also be due to negative cross-sectional correlation, as I find that it is statistically significant $(p<0.01)$ when I cluster across both firms and time. All Eq. (1) results are robust to twodimensional clustering; however, I report my results using standard errors clustered only by firm due to having an insufficient number of cluster dimensions (i.e., time periods), which could subject standard errors to significant dimensionality bias (Cameron et al. 2011; Cameron and Miller 2015).

${ }^{39}$ Ayers et al. (2009) also document that the information content of imputed taxable income is weaker for firms with high tax avoidance, so I also split my sample into firms with high and low cash effective tax rates. In untabulated results, I do not find any difference in results across high and low tax avoidance firms, indicating that my results are not driven by changes in tax avoidance that can accompany new loans (Gallemore et al. 2016). That my results do not vary across a source of noise in matching tax expense to cash taxes further suggests that the positive $T E$ coefficients I document are due to tax-related performance information, and not information about noise in tax expense.
} 
since the $I N S T \times P O S T \times T E$ coefficient reported in the bottom-right cell is positive and significant. As such, for firms where tax-related performance information is most important (i.e., high discretionary accrual firms; Ayers et al. 2009), I find that TRI is useful to equity investors. Further, that the TE coefficient increases with TRI suggests that the TRI is useful to equity investors because it either provides them with more tax-related performance information or more information about potential sources of noise in the ability of tax expense to map to cash tax payments.

For firms with low discretionary accruals in Panel C, I find that the TE coefficient is significantly positive for firms receiving non-institutional loans in both the pre- and post-loan periods; however, the $T E$ coefficient for firms receiving institutional loans is insignificantly negative in both the pre- and post-loan periods. Since all differences and the $I N S T \times P O S T \times T E$ coefficient for these firms are statistically insignificant, I cannot reject the null hypothesis that TRI is not useful to equity investors for these firms.

Finally, in Panel D of Table 2, I report the full regression analyses that support Panels A, B, and C (in columns 1,3 , and 4 , respectively). ${ }^{40}$ Inferences about the $T E$ coefficient and the type of information content TRI provides to equity investors are consistent whether levels or changes in $T E$ are used (i.e., $T E$ or $\triangle T E$ ) and whether the $C T R L$ vector of controls is included or not. ${ }^{41}$ This table also allows me to directly compare how the coefficients on PTI and TE move, and most importantly their triple interaction coefficient (with INST and POST). In columns 1 and 2 where I run Eq. (1) on the entire sample, the coefficients on $I N S T \times P O S T \times P T I$ (or $I N S T \times P O S T \times \triangle P T I$ ) are statistically positive. Since I find in Panel B that the usefulness of TRI causes an increase in the TE coefficient, this similar direction would suggest that I could be capturing non-tax performance information with my $T E$ coefficient, and thus not be capturing TRI.

\footnotetext{
${ }^{40}$ In untabulated analyses, I test the parallel trends assumption of a difference-in-differences estimator using a dynamic trend analysis (Autor 2003). Across tests of Eq. (1), I fail to find statistically significant trends in treatment leads that would indicate a violation of the parallel trend assumption, suggesting that the results and inferences from testing Eq. (1) are validly identified through a difference-in-differences design. I also find no significant evidence of learning (i.e., lagged treatment effects are all similar in size), suggesting an immediate effect of TRI on tax expense valuation.

${ }^{41}$ I choose not to include these controls in earlier columns to more clearly trade off information content in pre-tax earnings and tax expense, except to include IOPCT given its significant potential as a correlated omitted variable in my setting. All results remain the same when the additional control variables from Eq. (2) are included. Because I do not include control variables in this table except when firm fixed effects (which greatly complicate entropy balancing) are included, all results are reported without entropy balancing. However, all results are robust to entropy balancing.
} 
However, when I partition my sample into firms with high and low discretionary accruals, I find that the pattern of results is very different between $T E$ and PTI. Specifically, I find that the coefficient on $I N S T \times P O S T \times T E$ is always positive and significant for high discretionary accrual firms and either insignificant or significantly negative for low discretionary accrual firms. On the contrary, I find that the coefficient on $I N S T \times P O S T \times P T I$ is always significantly or insignificantly negative for high discretionary accrual firms, while it is always significantly or insignificantly positive for low discretionary accrual firms. In total, this pattern of results shows that, when I expect there to be transmission of TRI to equity markets, investors are differentially reacting to non-tax performance information in a very different way than they are reacting to tax-related performance information. This supports that the information investors are reacting to is uniquely related to taxes (e.g., TRI), and is not from a correlated, omitted source of information about pre-tax performance. ${ }^{42}$

While these results are for the entire sample period, there was an important change in TRI for tax years ending on December 31, 2004 and thereafter. For these years, the IRS required that firms file Schedule M-3, which requires significant detail on all differences between book and taxable income. This additional schedule is "one of the most important new sources of information...in the last 40 years" (Donohoe and McGill 2011,36), and represents an important exogenous shock to the information content of tax returns. ${ }^{43}$ I examine in Table 3 how the Eq. (1) results vary with the change in corporate income tax filing requirements from the implementation of the Schedule M-3. Specifically, I partition observations into those related to loans occurring entirely in the pre-Schedule M-3 implementation period (MSPOST=0; columns

\footnotetext{
${ }^{42}$ While I examine loan issuance events, it is possible that a similar pattern of results could be obtained by any similar sequence of observations. To test the uniqueness of my results, I perform a placebo test by randomly classifying 3,000 firm-years as institutional loan issuance dates, and an additional 12,000 firm-years as non-institutional loan issuance dates. These numbers were chosen to be greater than the number of loan events in my sample, meaning these tests on average have greater power to reject a false null hypothesis than reported results. Using 200 iterations, I find that my placebo results for Table 2 and Table 4 do not reject the null hypothesis significantly more than the 20 times that would be expected given a 0.1 significance cutoff (all $p>0.2$ ). I conclude that my results are not an artifact of my design, but that unique tax-related information is transmitted to equity markets following institutional loan issuances. ${ }^{43}$ Previous book-tax difference disclosure on the Schedule M-1 included 13 general line items, while Schedule M-3 includes over 90 detailed line items, most of which have four disclosure requirements each. Investors believed that this was an important change in TRI content available to tax authorities, as they reacted negatively to news about the implementation of Schedule M-3 (Donohoe and McGill 2011).
} 
1 and 3) and in the post-Schedule M-3 implementation period (M3POST=1; columns 2 and 4). If this schedule is useful to equity investors, the prior results from Table 2 should be different across the periods. ${ }^{44}$

These results show that tax response coefficients appear to be larger when investors have TRI (i.e., $I N S T \times P O S T \times T E$ ) only in the pre-Schedule M-3 period. Interpreting this result is difficult, though, as several things could lead to this decline in tax response coefficients, as described in Appendix A. First, TRI could be less valuable in the post-Schedule M-3 period, which would suggest that the Schedule M-3 is not useful to investors. Second, the Schedule M-3 could be useful to investors by providing them with more information about current or future cash tax payments (Hanlon et al. 2005). Third, the increased ability to map TRI into book income could help investors better understand the performance information in pre-tax book income (i.e., provide book-income-confirming tax information), which could result in investors finding less incremental performance information in taxable income (decreasing the tax response coefficient) and relying more on the performance information in pre-tax income (increasing the pre-tax earnings response coefficient). Unfortunately, I am unable to distinguish between these explanations with these tests; however, evidence from tests discussed in Section 5.3 is inconsistent with the first explanation, while I also find that the coefficient on $I N S T \times P O S T \times P T I$ is significantly more positive in the post-Schedule M-3 period, consistent with the third explanation. ${ }^{45}$ Together, this evidence suggests that the BTD

\footnotetext{
${ }^{44}$ I lose significant power in these tests by omitting loans which have years within their six-year window around loan issuance in both the pre- and post-Schedule M-3 period. In untabulated analyses, I alternately code M3POST as 1 for all observations in 2004 and thereafter and 0 for all observations in 2003 and before, and find similar results. Additionally, this pattern of results could be driven by the implementation of Reg. FD in 2000 if Reg. FD made TRI appear more valuable in the post-Reg. FD period. This could happen if TRI was frequently disclosed in the pre-Reg. FD period yet Reg. FD reduced firms' ability to selectively disclose TRI to analysts and other parties (Li et al. 2015). I address this by partitioning my sample into (a) the pre-Reg. FD and Schedule M-3 period, (b) the post-Reg. FD and pre-Schedule M-3 period, and (c) the post-Reg. FD and Schedule M-3 period. I find that the pattern of results for (b) closely approximates the pattern of results for (a), rather than for (c). While this test, consistent with other results, does not produce statistically significant differences across periods, it does provide qualitative evidence that my results are driven by Schedule M-3 implementation, rather than Reg. FD.

${ }^{45}$ The impact of TRI on tax response coefficients is not statistically significant across the pre- and post-Schedule M3 period, though this may be due to the standard errors being inflated by very high multicollinearity (VIF=39); however, the impact of TRI on earnings response coefficients is statistically significant across the pre- and postSchedule M-3 period $(p<0.01)$. Variance inflation factors as reported are based on tests across population subsamples, rather than a pure four-way interaction coefficient, and remain very high when all control variables are removed. In untabulated analyses, I find this pattern of results is most concentrated in firms with high discretionary accruals (HIDA $=1$ ), consistent with my results in Table 2 .
} 
information in the Schedule M-3 is useful to investors incremental to other TRI, though how it is useful (e.g., by providing additional information about cash tax payments or increasing investors' ability to map tax-related performance information to pre-tax performance) is unclear.

\subsection{Tax Anomaly Analyses}

To further triangulate the usefulness of TRI for equity investors, I also estimate Eq. (2). Eq. (2) tests whether TRI helps investors more efficiently value a firm by examining whether tax anomalies dissipate for loans with institutional investors (i.e., when investors are provided TRI). ${ }^{46}$ These results are reported in Table 4, Panels A through F, with the supporting regressions reported in Panel G. ${ }^{47}$

In Panel A, I examine whether investors price the information in tax expense surprises (TSUR) differently after they receive TRI. Across all four cells $(2 \times 2$ for firms before and after the issuance of a syndicated loan and between institutional and non-institutional loans) I fail to find any significant evidence of an anomaly related to TSUR ${ }^{48}$ However, I do find that the anomaly is much more likely to occur for firms in the pre-loan period that are going to receive an institutional loan, and that this effect is significantly reduced in the post-loan period for these firms when I expect that TRI will be transmitted to equity markets (i.e., there is a significant difference between these two cells and the $I N S T \times P O S T \times T S U R$ coefficient reported in the bottom-right cell is significant). These results suggest that the market differentially reacts to the tax information in financial statements when equity market participants are provided TRI, and that

\footnotetext{
${ }^{46}$ Additionally, Eq. (2) helps to ensure that the results from Eq. (1) are not caused by a decline in information available to investors about cash tax expenses in the post-institutional-loan issuance period, since it is unlikely a decline in information availability would decrease tax anomalies.

${ }^{47}$ Because my analysis takes the form of a difference-in-difference design, it does not make sense to run year-by-year regressions, and thus I use pooled OLS rather than Fama-MacBeth (Fama and MacBeth 1973) regressions. To address possible bias in standard errors due to cross-correlation, I include year fixed effects (Petersen 2009), though my results are robust to clustering standard errors by firm and year. I report my results using standard errors clustered only by firm due to having an insufficient number of cluster dimensions (i.e., time periods), which could subject standard errors to significant dimensionality bias (Cameron et al. 2011; Cameron and Miller 2015). While I only present results using entropy-balanced samples, I also find that my results hold when entropy-balancing is not used.

${ }^{48}$ Here I report both coefficients and abnormal returns based on a trading strategy that goes long in the upper decile of $T A X$ and shorts the lowest decile of TAX. These returns are calculated by multiplying the relevant standardized coefficient or standardized coefficient sum by an adjustment factor, which is the number of standard deviations that separate the $5^{\text {th }}$ and $95^{\text {th }}$ percentiles of $T A X$. The $5^{\text {th }}$ and $95^{\text {th }}$ percentiles were chosen for ease in comparing returns across prior literature, given the prevalence of using decile-ranked anomaly variables in prior literature and that the $5^{\text {th }}$ and $95^{\text {th }}$ percentiles lie midway in the first and tenth decile.
} 
equity market pricing efficiency with respect to tax information improves as equity markets receive TRI that more completely reveals the information contained in taxes (Bloomfield 2002). Further, this result is consistent with institutional investors being able to identify firms ex-ante with tax-related mispricing and choosing to participate in syndicated loans in part to obtain additional information, such as TRI, that can be traded on.

In Panel B, I examine the effect of TRI on investor pricing of TIBI. I find that the TIBI anomaly only significantly exists for firms that receive institutional loans in the pre-loan period, consistent again with institutional investors targeting their syndicated loan investments towards firms with the greatest taxrelated mispricing. Transforming this coefficient into an abnormal return based on a trading strategy that goes long in the upper decile of $T I B I$ and shorts the lowest decile of TIBI shows that this mispricing yields a significant $8.48 \%$ annual return. I also find that the transmission of TRI to equity markets significantly reduces this anomaly return by 92 percent, both overall and relative to the control sample (i.e., there is a significant difference in returns pre- and post- loan issuance for institutional loan borrowers and the $I N S T \times P O S T \times T I B I$ coefficient reported in the bottom-right cell is significant). ${ }^{49}$ Similar to $T S U R$, results for $T I B I$ are consistent with TRI helping equity investors more efficiently value tax information.

In Panels $C$ and D, I examine the TCCE and RTCC tax anomaly variables, respectively. While these variables are similar conceptually, I report results of both because Schmidt (2006) decomposes the TCC of earnings (TCCE) into both an initial and revised (RTCC) portion and finds an anomaly only with respect to the revised portion. Across these panels, I find a similar pattern of results for both of these variables, though consistent with Schmidt (2006) I find that my results are stronger in Panel D with RTCC. I find that these anomalies only significantly exist in the pre-loan period for institutional loan borrowers, with abnormal returns for a trading strategy of 2.48 (for $T C C E$ ) to 3.06 percent (for $R T C C$ ). I also find that the transmission of TRI significantly reduces these anomaly trading returns by 83 to 100 percent (i.e., there is a significant difference in returns pre- and post- loan issuance for institutional loan borrowers and the triple interaction

${ }^{49}(8.48 \%-0.64 \%) / 8.48 \%=0.92$, although the statistical insignificance of the anomaly in the post-issuance period for institutional borrowers suggests a 100 percent reduction. 
coefficients in the bottom-right cells are significant), consistent with TRI being useful to equity investors by helping them value firms more efficiently with regard to tax information. ${ }^{50}$

In Panel E of Table 4, I test whether TRI affects the NBTD anomaly. Similar to previous anomalies, I find that the NBTD anomaly only exists in the pre-loan period for institutional borrowers, with abnormal returns for a decile trading strategy of 2.74 percent. I also find that the transmission of TRI to equity markets significantly reduces this anomaly return by 75 percent relative to the control sample (i.e., the $I N S T \times P O S T \times N B T D$ coefficient reported in the bottom-right cell is significant). ${ }^{51}$ Yet again, these results support that tax returns are useful to equity investors..$^{52}$

In total, these anomaly results confirm a rejection of my null hypothesis, and show that tax returns are useful to investors by helping them more efficiently price tax-related information. Additionally, the positive and significant anomaly returns that exist in the pre-loan period for institutional borrowers suggests that institutional investors may be able to identify firms whose tax returns have the most valuable information ex-ante (i.e., the greatest opportunity to use TRI to obtain arbitrage returns), and choose to participate in loan syndicates in part to obtain this useful information. By participating in the syndicate and gaining TRI, these investors may be able to obtain arbitrage returns by trading on TRI. Thus obtaining tax returns may be an important reason for the increasing prevalence of institutions in the syndicated loan market (Taylor and Sansone 2007), and a previously undocumented determinant of institutions' syndicated

\footnotetext{
${ }^{50}(3.06 \%-0.53 \%) / 3.06 \%=0.83$, while the change in signs for the $T C C E$ anomaly and the statistical insignificance of both anomalies in the post-issuance period for institutional borrowers suggests a 100 percent reduction.

${ }^{51}(2.74 \%-0.69 \%) / 2.74 \%=0.75$, although the statistical insignificance of the anomaly in the post-issuance period for institutional borrowers suggests a 100 percent reduction.

${ }^{52}$ All Table 4 inferences remain the same when I replace industry fixed effects with firm fixed effects. In untabulated analyses, I test the parallel trends assumption of a difference-in-differences estimator using a dynamic trend analysis (Autor 2003). I do not find any statistically significant treatment leads for tests using TIBI and TCCE, indicating no violations of the parallel trends assumption for these tests. However, I do find statistically significant positive leads or trends in the period preceding the issuance of a loan for TSUR, RTCC, and NBTD, indicating a violation of the parallel trends assumption for these tests. Instead of biasing towards my results, however, this violation biases against finding results consistent with tax return usefulness for these anomalies, as the sign of the lead trend is opposite the sign of the difference-in-difference result. This means that the results for these anomalies may be understated in magnitude due to the adverse violation of parallel trends, yet all my inferences are robust to this violation. I also find no significant evidence of changes in tax anomaly arbitrage across treatment lags, suggesting that TRI has a speedy effect on abnormal returns to tax anomalies. That the effects of TRI also do not appear to wane across Eq. (1) or (2) is consistent with a continued flow of TRI to equity markets following institutional loan issuances (Lisowsky et al. 2017; Minnis and Sutherland 2017).
} 
loan investment decisions (Massoud et al. 2011).

Finally, in Panel F of Table 4, I examine PBTD as an anomaly variable. While Hanlon (2005) examines this variable for mispricing, her results are consistent with investors properly incorporating the information in positive BTDs into prices, and thus with no mispricing on this variable. Thus this variable acts as a placebo test, as I expect no significant mispricing or mispricing differentials when testing this variable. Consistent with this intuition, I find no significant evidence of mispricing in any of my four cells, or any significant differences in mispricing. Thus I infer that variables not associated with mispricing will not artificially produce the pattern of results I see for variables previously associated with mispricing. ${ }^{53}$

While these results confirm my inferences from testing Eq. (1), they do not reveal anything about the type of TRI that is valuable to investors. Thus I also use the exogenous shock to the information content of tax returns represented by the implementation of Schedule M-3 and examine how my Eq. (2) results vary before and after Schedule M-3 implementation. If this schedule is useful to equity investors, the prior results from Table 4 for $I N S T \times P O S T \times T A X$ should be stronger in the post-implementation period. Results of this test are reported in Table 5. I find that my prior results appear to be larger in the post-Schedule M-3 period, as $I N S T \times P O S T \times T A X$ coefficients are more negative for all five key tax anomalies. For TIBI and NBTD, only the post-Schedule M-3 coefficient is negative, suggesting that these anomalies in particular may be sensitive to whether investors have access to the Schedule M-3. These results suggest that the BTD information in Schedule M-3 may be particularly valuable to investors in pricing firms' equity. However, these differences are all statistically insignificant, since tests of differences take the form of a four-way interaction coefficient whose standard errors are subject to extreme multicollinearity. ${ }^{54}$

In further, untabulated analyses, I examine how the Table 4 results vary in settings where the

\footnotetext{
${ }^{53}$ Since I do not find results for PBTD here or in other analyses, I omit it from all subsequent tables. Note that Table 4, Panel $\mathrm{G}$ contains all the regressions that underlie the other panels of Table 4.

${ }^{54}$ Specifically, variance inflation factors (VIFs) for tests of differences across the pre- and post-Schedule M-3 periods range from 46 to 99 , indicating that very high multicollinearity is inflating standard errors of the test statistic. These VIFs are calculated based on separate pre- and post-M-3 samples, which should reduce multicollinearity. Further, replacing control variables with a select few principle components or omitting control variables entirely reduces VIFs to range from 23 to 59 , which means very high multicollinearity still inflates standard errors of the test statistic.
} 
usefulness of TRI is likely to vary. Across all five anomalies, I find that my results are generally stronger among smaller firms (where firms are split on median $L M V E$ ), firms with greater discretionary accruals (HIDA), and firms with less analyst coverage (where firms are split on median ANCOV), consistent with TRI being more useful when other information is less available and noisier and when tax-related mispricing is greater (Ayers et al. 2009; Baik et al. 2016). ${ }^{55}$ However, these differences, while directionally robust, are generally statistically insignificant, since tests of differences take the form of a four-way interaction coefficient whose standard errors are subject to significant multicollinearity. ${ }^{56}$

Finally, while I rely on tests of Eq. (1) to more directly contrast tax-related and non-tax-related (i.e., pre-tax) information, I also include a full set of difference-in-differences interactions with the non-tax anomaly variables ESUR, EPR, CFPR, and PTACC (both separately and together) in untabulated analyses. I continue to find statistically higher tax anomalies in the pre-loan period and a statistically significant reduction in tax anomalies in the post-loan period for institutional loan borrowers. However, I do not find any statistically significant evidence that any of these non-tax anomalies differ between institutional and non-institutional loan borrowers, suggesting either that the transmission of non-tax information about firm performance or accruals is limited or that this information is not incrementally different from other publiclyavailable information. Together with evidence from Eq. (1), this evidence suggests that I am capturing the transmission of information that is uniquely related to taxes (e.g., TRI).

\section{Conclusion}

I examine whether tax returns are useful to equity investors, providing much needed evidence to inform the policy debate over whether tax returns should be publicly disclosed (Lenter et al. 2003; Morris 2015) and further the literature on the information in tax disclosures (e.g., Hanlon et al. 2005; Ayers et al. 2009). Through robust empirical tests involving difference-in-differences designs, firm fixed effects,

\footnotetext{
${ }^{55}$ I do not find a significant difference in results when looking across U.S. domestic-only firms and multinational firms, suggesting that the usefulness of TRI does not vary across these types of firms. Since multinational firms have several additional filing requirements that U.S.-only firms do not have (e.g., Forms 1118 and 5471), this result suggests that these additional forms are not given to or transmitted by lenders, or that they may not be useful to equity investors. ${ }^{56}$ For example, variance inflation factors for tests of differences across high- and low-size firms (split at the median) range from 13 to 34 , indicating that high to very high multicollinearity is inflating standard errors of the test statistic.
} 
entropy balancing, placebo tests, and many controls, I find strong evidence that TRI is useful to equity investors. Specifically, I document that tax response coefficients increase and tax-related market anomalies decline following the issuance of a syndicated loan where lenders obtain tax returns (Lisowsky et al. 2017), but only for loans designed for institutional investors who can transmit the information to equity markets (Bushman et al. 2010; Ivashina and Sun 2011). I also document evidence of greater tax-related market anomalies in the lead-up to the issuance of an institutional syndicated loan, consistent with institutional investors considering the usefulness of TRI in determining their loan syndicate participation. Finally, I show that the Schedule M-3 may be a significant source of the information obtained by equity investors from tax returns.

While this evidence supports public disclosure of tax returns, whether tax returns are useful to investors is only one facet of the debate over public disclosure of tax returns. Further research is needed regarding other facets of the debate so that other potential costs (e.g., taxable income manipulation; Hasegawa et al. 2013) and benefits (e.g., greater taxable income reporting under social pressure; Bø et al. 2015) can be weighed in determining the total net effect of tax return disclosure to society. Because I examine a setting without public disclosure, I can clearly identify the usefulness of TRI to equity investors absent confounding effects. However, it is possible that the usefulness of TRI to equity investors would be different in a setting with public disclosure, particularly if public disclosure incentivizes companies to manipulate tax amounts (Hasegawa et al. 2013). Further, my results are obtained using data on U.S. companies and investors, and thus may not apply to other countries with different regulatory, economic, legal, cultural, and reporting features. In particular, my results may not generalize to countries with greater book-tax conformity than the U.S., as there is likely to be less unique information in tax returns relative to financial statements in these settings (Hanlon et al. 2008). Further research in other countries is needed to examine the extent to which tax returns may or may not be useful when these features change or when other facets of the tax return disclosure debate may interact with tax return usefulness. 


\section{Appendix A: Interpreting the Coefficient on $T E$}

As previously described in Section 2.2, a large literature examines the information content of tax information provided in financial statements (e.g., Hanlon et al. 2005; Ayers et al. 2009). This literature examines information value relevance by regressing concurrent returns on a measure of book earnings and a measure of tax earnings, such as the following regression: ${ }^{57}$

$$
\operatorname{RRET}_{i t}=\beta_{0}+\beta_{1} P T I_{i t}+\beta_{2} T E_{i t}+\epsilon_{i t}
$$

Here, taxes are deemed to have information content and value relevance if the coefficient on taxes $\left(\beta_{2}\right)$ is statistically significant.

To interpret the coefficient on $T E$, prior literature highlights that taxable income (and its transformation, tax expense) factors into firm value in two different ways (Thomas and Zhang 2014). First, taxable income (as a linear transformation of tax expense) matches cash payments to tax authorities with book income, and thus should be negatively valued by investors as tax expense represents cash outflows to tax authorities (Lipe 1986). Second, taxable income effectively measures firm performance (i.e., profitability) according to tax accounting rules (Shevlin 2002). As discussed in Section 2.2, there are many circumstances where tax accounting may plausibly map into firm performance incremental to GAAP, and possibly where tax accounting is even preferable to GAAP at measuring firm performance. Thus, taxable income may capture firm performance incremental to GAAP income, and thus be positively valued by investors who view taxable income as an alternate measure of firm profitability.

Absent the proxy-for-profitability role of taxable income, the coefficient on $T E$ should be negative. Ignoring the consequences of $T E$ for future periods and assuming that $T E$ perfectly matches cash tax payments to book income, then the coefficient on $T E$ should be -1 . When $T E$ does not perfectly match cash tax payments to book income, then the coefficient on $T E$ will be smaller (i.e., greater than -1); this would be the case if tax expense contains noise (e.g., the manipulation of tax accounts to manage earnings) or if

\footnotetext{
${ }^{57}$ Book earnings may be computed before or after tax, depending on whether pre-tax imputed taxable income (or tax expense) or post-tax imputed taxable income is used as the tax earnings variable. Prior literature uses both earnings levels and earnings changes (i.e., unexpected earnings). Subscripts are for firm $i$ at time $t$.
} 
certain tax accruals are not expected to translate into cash tax payments (e.g., uncertain tax positions that are not expected to be overturned by a tax audit). On the other hand, the coefficient on $T E$ may be larger (i.e., less than -1) if $T E$ contains information about future cash tax payments, such as a tax expense surprise that is expected to persist into future periods (Ohlson 1999; Elliott et al. 2015).

However, once the proxy-for-profitability role of taxable income is considered, it is entirely possible that the coefficient on $T E$ will become positive; indeed, this is generally what prior literature finds (Hanlon et al. 2005; Ayers et al. 2009). Similar to the matching role of taxable income, the effect of the proxy-for-profitability role on the $T E$ coefficient can be affected by measurement error and future implications. If taxable income contains measurement error in capturing firm performance or contains less information about firm performance incremental to book income, then the coefficient on $T E$ will be smaller (i.e., less positive or more negative). On the other hand, the coefficient on $T E$ may be larger (i.e., more positive or less negative) if $T E$ contains information about future firm performance, such as a firm performance surprise that is expected to persist into future periods (Ohlson 1999; Elliott et al. 2015).

Thomas and Zhang (2014) add to this literature by illustrating how the findings of this literature change when considering the role of concurrent changes in expectations of future earnings, following Liu and Thomas (2000). Liu and Thomas show that concurrent returns are both a function of news about concurrent earnings and changes in expectations about future earnings. By controlling for these changes in expectations about future earnings, Liu and Thomas find that the $\mathrm{R}^{2}$ of returns-earnings regressions increase and earnings response coefficients grow closer to the theoretical value of 1 that would be expected absent noise in earnings or implications about future earnings. Thomas and Zhang (2014) incorporate controls for changes in expectations about future earnings into Eq. (3), and find that this suppresses the proxy-forprofitability role of taxable income. Without this role, the matching role of taxable income dominates and the coefficient on $T E$ becomes negative and closer to the "theoretically correct" value of -1 .

I contribute to the literature on the information content of taxes by considering whether TRI is useful to equity investors incremental to financial statement information. Because one way in which TRI may be useful to equity investors is to provide them with more information about firm performance, it is 
important in my setting that I do not control for changes in expectations in future earnings, as I do not want to suppress the proxy-for-profitability role of taxable income. However, there is another important reason to not control for changes in expectations about future earnings. Future earnings expectations are calculated using analyst forecasts (Liu and Thomas 2000; Thomas and Zhang 2014). Because information about firm performance contained in TRI could influence investors and analysts' expectations of future profitability, particularly if analysts are also being provided TRI by their affiliated bank or institution (Chen and Martin 2011), controlling for changes in expectations about future GAAP earnings may unnecessarily control for the very TRI I hope to capture.

I use a model of the information content of financial statement tax expense to help me identify the effect of TRI. I expect that, if TRI is useful to equity investors, then they will update their beliefs about the value of the firm using this information. This will result in TRI being reflected in stock returns. ${ }^{58}$ This difference in returns without a change in tax expense will likely affect the $T E$ coefficient, with the effect depending on (a) the sign of the baseline TE coefficient, (b) the reason why TRI is useful to investors, and (c) the type of information provided by tax returns. For this discussion, I assume that the baseline $T E$ coefficient is positive, since that is what prior literature finds (e.g., Hanlon et al. 2005; Ayers et al. 2009) and what I find in my analyses (see Section 5.2).

If TRI provides investors with new information they did not previously have access to, and this new information is not partially correlated with financial statement tax expense, this will result in increased stock return variance that is uncorrelated with tax expense, which will shrink the size of the $T E$ coefficient (i.e., make the baseline less positive). If TRI either (a) provides investors with new information they did not previously have access to and this information is at least partially correlated with financial statement tax expense or (b) helps investors better understand the information inherent in financial statement tax

\footnotetext{
${ }^{58}$ However, I do not expect the provision of TRI to investors to change tax expense or pre-tax income, or the ability of tax expense to predict future earnings. In untabulated analyses, I replace stock returns as my dependent variable with returns on assets, and find no evidence that my difference-in-differences coefficient on $T E$ is significant for current return on assets or the return on assets for the following two years, consistent with the predictive ability of tax expense for firm profitability not differing for firms who receive an institutional syndicated loan.
} 
expense, then the effect on the $T E$ coefficient depends on the type of information provided by tax returns.

As discussed above, tax expense has two types of information that are value relevant: information about cash tax payments and information about firm performance. Furthermore, TRI has four types of information that might affect the association between returns and tax expense, which are related to the four reasons given above why the $T E$ coefficient might deviate from -1. First, TRI might contain information about the noise inherent in the mapping of cash tax payments to book income. This type of information will reduce the matching role of tax expense, and thus increase the TE coefficient. Second, TRI might contain additional information about current or future cash tax payments. This information will result in an increased matching role for tax expense, and should be reflected as a decrease in the $T E$ coefficient. Third, TRI could contain additional information about a firm's current or future performance. This information would increase the proxy-for-profitability role of tax expense, leading to an increase in the $T E$ coefficient. Fourth and finally, TRI may provide information that helps investors better map the firm performance information in tax expense to book income. This increased mapping will increase the amount of variation in stock returns that is shared between tax expense and book income. Because regression analysis removes common variation between variables from coefficients, this will shrink the $T E$ coefficient (i.e., make the baseline less positive) ${ }^{59}$

While these many moving parts make exact interpretations of the $T E$ coefficient difficult (e.g., because both positive and negative changes in the coefficient have multiple explanations), this test also has another benefit. Specifically, this test enables me to compare how information about pre-tax income and tax expense changes relative to each other. This is important because I do not directly observe the transmission or nature of TRI, and thus I can differentiate whether the information I capture is tax-specific or simply correlated information about pre-tax performance. If the coefficients on pre-tax income (e.g., $P T I)$ and tax expense (e.g., $T E$ ) change in unique ways, this would provide evidence that the information investors are receiving is tax-related and not simply correlated information about pre-tax performance.

59 To the extent confirmatory tax information increases investors' trust in and use of pre-tax book income, this information could also lead to an increased pre-tax book income valuation. 


\title{
Appendix B: Variable Definitions
}

\section{Return Variables RRET}

MRET

FFRET

LRET
Annual buy-and-hold returns, computed beginning in the third month of the fiscal year and continuing until three months after the end of the fiscal year Annual buy-and-hold returns adjusted for annual buy-and-hold market returns, computed beginning in the third month of the fiscal year and continuing until three months after the end of the fiscal year

Annual buy-and-hold abnormal returns, computed beginning in the third month of the following fiscal year $(t+1)$ and continuing until three months after the end of the following fiscal year (i.e., at the end of the third month of $t+2$ ). Abnormal returns are computed monthly using the Fama and French (2015) Five-Factor methodology, before being aggregated to an annual abnormal return. Monthly return regressions are run over the preceding 48 months and require that returns for at least 24 of those months be present. Annual buy-and-hold returns, computed over the fiscal year

\section{Difference-in-Differences Variables}

INST

Indicator variable equal to 1 if a firm issues a Term Loan B, C, D, E, or F, and 0 otherwise (Bushman and Wittenberg-Moerman 2012)

POST Indicator variable equal to 1 in the year of a loan syndication and the following two years, and 0 otherwise

\author{
Primary Tax and Earnings Variables \\ PTI Pre-tax income, computed as pre-tax income (pi) scaled by lagged market value \\ of equity (prcc_f $\times$ csho) \\ TE Tax expense, computed as total tax expense (txt) scaled by lagged market value \\ of equity (prcc_f $\times$ csho) \\ $\triangle P T I \quad$ Pre-tax income change, computed as the difference in pre-tax income (pi) \\ between the current and prior year scaled by lagged market value of equity \\ (prcc_f $\times$ csho) \\ $\triangle T E \quad$ Tax expense change, computed as the difference in total tax expense (txt) \\ between the current and prior year scaled by lagged market value of equity \\ (prcc_f $\times$ csho) \\ TSUR Tax expense surprise, computed as the annual change in tax expense per share \\ (txt/csho), scaled by lagged total assets per share (at/csho) \\ TIBI Taxable income/book income, computed as taxable income divided by book \\ income (ib). Taxable income is computed as current tax expense (txt - txdi) \\ multiplied by $(1-\mathrm{T}) / \mathrm{T}$, where $\mathrm{T}$ is the top U.S. corporate tax rate. \\ TCCE Tax change component of earnings, computed as the annual change in the ratio of \\ tax expense to pre-tax income (txt/pi) multiplied by earnings per share (pi/csho) \\ and scaled by lagged total assets per share (at/csho) \\ RTCC Revised tax change component of earnings, computed as the change in the ratio \\ of tax expense to pre-tax income (txt/pi - txty/piy) from the end of the first \\ quarter to the end of the fourth quarter of the fiscal year multiplied by earnings \\ per share (pi/csho) and scaled by lagged total assets per share (at/csho) \\ PBTD Positive book-tax differences, computed as deferred tax expense (txdi) multiplied \\ by $-1 / T$, where $T$ is the top U.S. corporate tax rate, and scaled by lagged total \\ assets (at). Computed only for firm-years with positive book-tax differences.
}



total assets (at). Computed only for firm-years with negative book-tax differences.

\author{
Cross-Sectional Analysis Variables \\ M3POST \\ Indicator variable equal to 1 for syndicated loan issuances occurring in 2007 or \\ later, so that the entire six-year issuance window occurs post Schedule M-3 \\ implementation, and 0 for syndicated loan issuances occurring in 2001 or earlier, \\ so that the entire six-year issuance window occurs pre Schedule M-3 \\ implementation \\ HIDA Indicator variable equal to 1 if the Modified Jones model (Dechow et al. 1995) \\ abnormal accrual estimated by lifecycle and year (Chang and Li 2016) is above \\ the median for the full sample, and 0 otherwise
}

\section{Control Variables $I O P C T$}

ANCOV

ISPEC

REST

SECD

$S P I$

NOL

$B T M$

BETA

RVOL

LMVE

GASUR

ESUR

SSUR

$E P R$
The percentage of stock held by institutional owners as defined by the Thomson Reuters $13 \mathrm{~F}$ database

Analyst coverage, computed as $\ln (\mathrm{A}+1)$, where $\mathrm{A}$ is the average number of analysts providing earnings forecasts at any point during the year from $\mathrm{I} / \mathrm{B} / \mathrm{E} / \mathrm{S}$

Indicator variable equal to 1 if the lead arranger on the loan being issued is an industry specialist, and 0 otherwise. An industry specialist is defined as being one of the three largest lead arrangers by total loan value within a three-digit SIC industry.

Indicator variable equal to 1 if the loan being issued has a primary purpose in DealScan of "LBO", "MBO", “Takeover", "Recap.", or "Merger", and 0 otherwise Indicator variable equal to 1 if the loan being issued is secured, and 0 otherwise Special purpose items, computed as special purpose items (spi), scaled by lagged total assets (at). Where missing, I replace spi with 0.

Net operating loss carryforwards, computed as tax loss carryforwards (tlcf) scaled by lagged total assets (at). Where missing, I replace tlcf with 0.

Book-to-market value of equity, computed as the book value of equity (seq) divided by the market value of equity (prec_f $\times$ csho)

Market beta, computed as the coefficient on the market return less the risk-free rate from the Fama-French five factor regressions.

Return volatility, computed as the root mean squared error from the Fama-French five factor regressions

Logged market value of equity, computed as the natural $\log$ of a firm's market value of equity (prcc_f $\times$ csho)

Selling, general, and administrative expense surprise, computed as the annual change in selling, general, and administrative expense per share (xsga/csho), scaled by lagged total assets per share (at/csho)

Earnings surprise, computed as the annual change in earnings per share (ib/csho), scaled by lagged total assets per share (at/csho)

Sales surprise, computed as the annual change in sales per share (sale/csho), scaled by lagged total assets per share (at/csho)

Earnings to price ratio, computed as earnings per share (ib/csho) divided by stock price (prec_f) 
Cash flow to price ratio, computed as net operating cash flows per share (oancf/csho) divided by lagged stock price (prcc_f)

PTACC Pre-tax accruals, computed as pre-tax income (pi) less pre-tax cash flows from operations (oancf + txpd), scaled by lagged total assets (at)

DXFIN Cash flow received from net financing activities, computed as stock issuances (sstk) plus debt issuances (dltis) plus changes in the current portion of long-term debt (dlcch), less stock repurchases (prstkc), cash dividends (dv), and debt reductions (dltr), all scaled by lagged total assets (at). Where changes in current debt (dlcch) is missing, I replace it with 0. 


\section{References}

Acharya, V. and T. Johnson. 2010. More Insiders, More Insider Trading: Evidence from Private-Equity Buyouts. Journal of Financial Economics 98: 500-523.

Addoum, J. and J. Murfin. 2016. Hidden in Plain Sight: Equity Price Discovery with Informed Private Debt. Working paper, Cornell University.

Aston, H. 2016. Scott Morrison's Tax Advisors Want Public 'Educated' on Low Corporate Tax. The Sydney Morning Herald January 28, 2016.

Atwood, T.J., M. Drake, and L. Myers. 2010. Book-Tax Conformity, Earnings Persistence and the Association between Earnings and Future Cash Flows. Journal of Accounting and Economics 50: 111125.

Autor, D. 2003. Outsourcing at Will: The Contribution of Unjust Dismissal Doctrine to the Growth of Employment Outsourcing. Journal of Labor Economics 21(1): 1-42.

Ayers, B., J. Jiang, and S. Laplante. 2009. Taxable Income as a Performance Measure: The Effects of Tax Planning and Earnings Quality. Contemporary Accounting Research 26(1): 15-54.

Ayers, B., S. Laplante, and S. McGuire. 2010. Credit Ratings and Taxes: The Effect of Book-Tax Differences on Ratings Changes. Contemporary Accounting Research 27(2): 359-402.

Badertscher, B., J. Phillips, M. Pincus, and S. Rego. 2009. Earnings Management Strategies and the TradeOff between Tax Benefits and Detection Risk: To Conform or Not to Conform? The Accounting Review 84(1): 63-97.

Baginski, S. 1987. Intraindustry Information Transfers Associated with Management Forecasts of Earnings. Journal of Accounting Research 25(2): 196-216.

Baik, B., K. Kim, R. Morton, and Y. Roh. 2016. Analysts' Pre-Tax Income Forecasts and the Tax Expense Anomaly. Review of Accounting Studies 21: 559-595.

Ball, R., and P. Brown. 1968. An Empirical Evaluation of Accounting Income Numbers. Journal of Accounting Research 6(2): 159-178.

Ball, R., X. Li, and L. Shivakumar. 2015. Contractibility and Transparency of Financial Statement Information Prepared Under IFRS: Evidence from Debt Contracts Around IFRS Adoption. Journal of Accounting Research 53(5): 915-963.

Beaver, W., M. McNichols, and R. Price. 2007. Delisting Returns and Their Effect on Accounting-Based Market Anomalies. Journal of Accounting and Economics 43: 341-368.

Beyer, A., D. Cohen, T. Lys, and B. Walther. 2010. The Financial Reporting Environment: Review of the Recent Literature. Journal of Accounting and Economics 50: 296-343.

Blackburne, T. and J. Blouin. 2016. Understanding the Information Content of Book-Tax Differences. Working paper, University of Washington.

Bloomfield, R. 2002. The "Incomplete Revelation Hypothesis" and Financial Reporting. Accounting Horizons 16(3): 233-243.

Bø, E., J. Slemrod, and T. Thoresen. 2015. Taxes on the Internet: Deterrence Effects of Public Disclosure. American Economic Journal: Economic Policy 7(1): 36-62.

Botosan, C. and M. Stanford. 2005. Managers' Motives to Withhold Segment Disclosures and the Effect of SFAS No. 131 on Analysts' Information Environment. The Accounting Review 80(3): 751-771.

Bradshaw, M., S. Richardson, and R. Sloan. 2006. The Relation between Corporate Financing Activities, Analyst's Forecasts and Stock Returns. Journal of Accounting and Economics 42: 53-85. 
Bushman, R., A. Smith, and R. Wittenberg-Moerman. 2010. Price Discovery and Dissemination of Private Information by Loan Syndicate Participants. Journal of Accounting Research 48(5): 921-972.

Bushman, R. and R. Wittenberg-Moerman. 2012. The Role of Bank Reputation in "Certifying" Future Performance Implications of Borrowers' Accounting Numbers. Journal of Accounting Research 50(4): 883-930.

Cameron, A.C., J. Gelbach, and D. Miller. 2011. Robust Inference with Multiway Clustering. Journal of Business \& Economic Statistics 29(2): 238-249.

Cameron, A.C. and D. Miller. 2015. A Practitioner's Guide to Cluster-Robust Inference. Journal of Human Resources 50(2): 317-372.

Chang, H. and L.Y. Li. 2016. Firm Life Cycle and Detection of Accrual-Based Earnings Manipulation. Working paper, Singapore Management University.

Chava, S. and M. Roberts. 2008. How Does Financing Impact Investment? The Role of Debt Covenants. Journal of Finance 63(5): 2085-2121.

Chen, T. and X. Martin. 2011. Do Bank-Affiliated Analysts Benefit from Lending Relationships? Journal of Accounting Research 49(3): 633-675.

Cheng, L., M. Cheng, D. Dhaliwal, and S. Kaplan. 2016. Bank Auditor Connection and Audit Quality. Working paper, University of Arizona.

Chi, S., M. Pincus, and S.H. Teoh. 2014. Mispricing of Book-Tax Differences and the Trading Behavior of Short Sellers and Insiders. The Accounting Review 89(2): 511-543.

Crabtree, A. and J. Maher. 2009. The Influences of Differences in Taxable Income and Book Income on the Bond Credit Market. Journal of the American Taxation Association 31(1): 75-99.

Cremers, K.J.M. and V. Nair. 2005. Governance Mechanisms and Equity Prices. Journal of Finance 60(6): 2859-2894.

Dechow, P., R. Sloan, and A. Sweeney. 1995. Detecting Earnings Management. The Accounting Review 70(2): 193-225.

Demeré, P. and J. Gramlich. 2017. The Value of International Income Shifting Opportunities to U.S. Multinational Firms. Working paper, University of Illinois.

Dennis, S. and D. Mullineaux. 2000. Syndicated Loans. Journal of Financial Intermediation 9: 404-426.

Desai, H., S. Rajgopal, and M. Venkatachalam. 2004. Value-Glamour and Accruals Mispricing: One Anomaly or Two? The Accounting Review 79(2): 355-385.

Dhaliwal, D., H.S. Lee, M. Pincus, and L. Steele. 2017. Taxable Income and Firm Risk. Journal of the American Taxation Association 39(1): 1-24.

Dichev, I. and V.W. Tang. 2008. Matching and the Changing Properties of Accounting Earnings over the Last 40 Years. The Accounting Review 83(6): 1425-1460.

Dietrich, J.R., S. Kachelmeier, D. Kleinmuntz, and T. Linsmeier. 2001. Market Efficiency, Bounded Rationality, and Supplemental Business Reporting Disclosures. Journal of Accounting Research 39(2): 243-268.

Donohoe, M. and G. McGill. 2011. The Effects of Increased Book-Tax Difference Tax Return Disclosures on Firm Valuation and Behavior. Journal of the American Taxation Association 33(2): 35-65.

Donohoe, M., G. McGill, and E. Outslay. 2012. Through a Glass Darkly: What Can We Learn about a U.S. Multinational Corporation's International Operations from Its Financial Statement Disclosures? National Tax Journal 65(4): 961-984. 
Elliott, W.B., K. Jackson, M. Peecher, and B. White. 2014. The Unintended Effect of Corporate Social Responsibility Performance on Investors' Estimates of Fundamental Value. The Accounting Review 89(1): 275-302.

Elliott, W.B., J. Hobson, and B. White. 2015. Earnings Metrics, Information Processing, and Price Efficiency in Laboratory Markets. Journal of Accounting Research 53(3): 555-592.

Erickson, M., M. Hanlon, and E. Maydew. 2004. How Much Will Firms Pay for Earnings That Do Not Exist? Evidence of Taxes Paid on Allegedly Fraudulent Earnings. The Accounting Review 79(2): 387408.

Ernst \& Young. 2016. Report on Recent U.S. International Tax Developments - 11 March 2016. EY Tax Insights March 11, 2016.

Evershed, N. and D. Hurst. 2015. ATO Report Shows Nearly 600 Big Companies Paid No Tax in 2013-14. The Guardian December 16, 2015.

Everson, M. 2008. A Reform Tool: Tax Returns. The Washington Post October 18, 2008.

Fama, E. and J. MacBeth. 1973. Risk, Return, and Equilibrium: Empirical Tests. Journal of Political Economy 81(3): 607-636.

Fama, E. and K. French. 2015. A Five-Factor Asset Pricing Model. Journal of Financial Economics 116: $1-22$.

Financial Accounting Standards Board (FASB). 1978. Objectives of Financial Reporting by Business Enterprises (Statement of Financial Accounting Concepts No. 1). FASB: Norwalk, CT.

Foley, C.F., J. Hartzell, S. Titman, and G. Twite. 2007. Why Do Firms Hold So Much Cash? A Tax-Based Explanation. Journal of Financial Economics 86: 579-607.

Foster, G. 1981. Intra-Industry Information Transfers Associated with Earnings Releases. Journal of Accounting and Economics 3: 201-232.

Frischmann, P., T. Shevlin, and R. Wilson. 2008. Economic Consequences of Increasing the Conformity in Accounting for Uncertain Tax Benefits. Journal of Accounting and Economics 46: 261-278.

Gallemore, J., B. Gipper, and E. Maydew. 2016. Banks as Tax Planning Intermediaries. Working paper, University of Chicago.

Gao, Z., D. Givoly, and R. Laux. 2015. Assessing the Relation between Taxes and Stock Returns: The Critical Role of Choosing the Tax Variable. Working paper, Lancaster University.

Gleason, C., N. Jenkins, and W.B. Johnson. 2008. The Contagion Effects of Accounting Restatements. The Accounting Review 83(1): 83-110.

Gorton, G. and G. Pennacchi. 1995. Banks and Loan Sales: Marketing Nonmarketable Assets. Journal of Monetary Economics 35: 389-411.

Graham, J. 1996. Proxies for the Corporate Marginal Tax Rate. Journal of Financial Economics 42: 187221.

Graham, J., J. Raedy, and D. Shackelford. 2012. Research in Accounting for Income Taxes. Journal of Accounting and Economics 53: 412-434.

Hainmueller, J. 2012. Entropy Balancing for Causal Effects: A Multivariate Reweighting Method to Produce Balanced Samples in Observational Studies. Political Analysis 20: 25-46.

Hanlon, M. 2003. What Can We Infer about a Firm's Taxable Income from Its Financial Statements? National Tax Journal 56(4): 831-863.

Hanlon, M. 2005. The Persistence and Pricing of Earnings, Accruals, and Cash Flows When Firms Have Large Book-Tax Differences. The Accounting Review 80(1): 137-166. 
Hanlon, M., S. Laplante, and T. Shevlin. 2005. Evidence for the Possible Information Loss of Conforming Book Income and Taxable Income. Journal of Law and Economics 48(2): 407-442.

Hanlon, M., E. Maydew, and T. Shevlin. 2008. An Unintended Consequence of Book-Tax Conformity: A Loss of Earnings Informativeness. Journal of Accounting and Economics 46: 294-311.

Hanlon, M. and S. Heitzman. 2010. A Review of Tax Research. Journal of Accounting and Economics 50: 127-178.

Hasegawa, M., J. Hoopes, R. Ishida, and J. Slemrod. 2013. The Effect of Public Disclosure on Reported Taxable Income: Evidence from Individuals and Corporations in Japan. National Tax Journal 66(3): 571-608.

Henry, E. 2014. The Information Content of Tax Expense: A Discount Rate Explanation. Working paper, University of Tennessee.

Hepfer, B. 2016. A Closer Examination of the Book-Tax Difference Pricing Anomaly. Working paper, Texas A\&M University.

Hirshleifer, D. and S.H. Teoh. 2003. Limited Attention, Information Disclosure, and Financial Reporting. Journal of Accounting and Economics 36: 337-386.

Hirst, D.E. and P. Hopkins. 1998. Comprehensive Income Reporting and Analysts' Valuation Judgments. Journal of Accounting Research 36(Supplement): 47-75.

Hoopes, J., L. Robinson, and J. Slemrod. 2016. The Impact of Public Tax-Return Disclosure. Working paper, University of North Carolina at Chapel Hill.

Hutchens, M. 2016. How Do Disclosure Characteristics Affect Forecast Accuracy? Working paper, University of Illinois at Urbana-Champaign.

Ivashina, V., V. Nair, A. Saunders, N. Massoud, and R. Stover. 2009. Bank Debt and Corporate Governance. Review of Financial Studies 22(1): 42-77.

Ivashina, V. and Z. Sun. 2011. Institutional Stock Trading on Loan Market Information. Journal of Financial Economics 100: 284-303.

Jiang, W., K. Li, and P. Shao. 2010. When Shareholders are Creditors: Effects of the Simultaneous Holding of Equity and Debt by Non-Commercial Banking Institutions. Review of Financial Studies 23(10): 35953637.

Kerr, J. 2016. Why Are Taxes Value Relevant? Cross-Country Evidence on the Proxy for Profitability Role of Tax Surprise. Working paper, Baruch College - CUNY.

Kim, S., A. Koester, and S. Lim. 2015. The Substitutive Role of Taxable Income when Book Income is Less Informative. Working paper, University of Massachusetts - Boston.

Kim, S., A. Schmidt, and K. Wentland. 2015. Analysts and Taxes. Working paper, University of Massachusetts - Boston.

Koester, A. 2011. Investor Valuation of Tax Avoidance Through Uncertain Tax Positions. Working paper, Georgetown University.

Kornhauser, M. 2010. Shaping Public Opinion and the Law: How a "Common Man" Campaign Ended a Rich Man's Law. Law and Contemporary Problems 73(1): 123-147.

Kothari, S.P. 2001. Capital Markets Research in Accounting. Journal of Accounting and Economics 31: 105-231.

Lang, L. and R. Stulz. 1992. Contagion and Competitive Intra-Industry Effects of Bankruptcy Announcements: An Empirical Analysis. Journal of Financial Economics 32: 45-60.

Larcker, D., S. Richardson, and I. Tuna. 2007. Corporate Governance, Accounting Outcomes, and Organizational Performance. The Accounting Review 82(4): 963-1008. 
Lenter, D., J. Slemrod, and D. Shackelford. 2003. Public Disclosure of Corporate Tax Return Information: Accounting, Economics, and Legal Perspectives. National Tax Journal 56(4): 803-830.

Lester, R. 2015. Made in the U.S.A.? A Study of Firm Responses to Domestic Production Incentives. Working paper, Stanford University.

Lev, B. and D. Nissim. 2004. Taxable Income, Future Earnings, and Equity Values. The Accounting Review 79(4): 1039-1074.

Li, Y., A. Saunders, and P. Shao. 2015. Did Regulation Fair Disclosure Affect Credit Markets? Journal of Banking \& Finance 54: 46-59.

Lipe, R. 1986. The Information Contained in the Components of Earnings. Journal of Accounting Research 24(Supplement): 37-64.

Lisowsky, P., M. Minnis, and A. Sutherland. 2017. Economic Growth and Financial Statement Verification. Journal of Accounting Research, Forthcoming.

Liu, C., S. Ryan, and J. Wahlen. 1997. Differential Valuation Implications of Loan Loss Provisions Across Banks and Fiscal Quarters. The Accounting Review 72(1): 133-146.

Liu, J. and J. Thomas. 2000. Stock Returns and Accounting Earnings. Journal of Accounting Research 38(1): 71-101.

Lundholm, R., R. Rogo, and J.L. Zhang. 2014. Restoring the Tower of Babel: How Foreign Firms Communicate with U.S. Investors. The Accounting Review 89(4): 1453-1485.

Maines, L. and L. McDaniel. 2000. Effects of Comprehensive-Income Characteristics on Nonprofessional Investors' Judgments: The Role of Financial-Statement Presentation Format. The Accounting Review 75(2): 179-207.

Manzon, G. and G. Plesko. 2002. The Relation Between Financial and Tax Reporting Measures of Income. Tax Law Review 55: 175-214.

Massoud, N., D. Nandy, A. Saunders, and K. Song. 2011. Do Hedge Funds Trade on Private Information? Evidence from Syndicated Lending and Short-Selling. Journal of Financial Economics 99: 477-499.

McGill, G. and E. Outslay. 2004. Lost in Translation: Detecting Tax Shelter Activity in Financial Statements. National Tax Journal 57(3): 739-756.

Mills, L. and G. Plesko. 2003. Bridging the Reporting Gap: A Proposal for More Informative Reconciling of Book and Tax Income. National Tax Journal 56(4): 865-893.

Minnis, M. and A. Sutherland. 2017. Financial Statements as Monitoring Mechanisms: Evidence from Small Commercial Loans. Journal of Accounting Research 55(1): 197-233.

Morris, D. 2015. A Case for Company-Specific Public Disclosure of Corporate Tax Returns. Accounting and the Public Interest 15(1): 1-21.

Ohlson, J. 1999. On Transitory Earnings. Review of Accounting Studies 4: 145-162.

Petersen, M. 2009. Estimating Standard Errors in Finance Panel Data Sets: Comparing Approaches. Review of Financial Studies 22(1): 435-480.

Plesko, G. 2003. An Evaluation of Alternative Measures of Corporate Tax Rates. Journal of Accounting and Economics 35: 201-226.

Plumlee, M. 2003. The Effect of Information Complexity on Analysts' Use of That Information. The Accounting Review 78(1): 275-296.

Raedy, J., J. Seidman, and D. Shackelford. 2011. Is There Information in the Tax Footnote? Working paper, University of North Carolina.

Schmidt, A. 2006. The Persistence, Forecasting, and Valuation Implications of the Tax Change Component of Earnings. The Accounting Review 81(3): 589-616. 
Scholes, M., G.P. Wilson, and M. Wolfson. 1992. Firms' Responses to Anticipated Reductions in Tax Rates: The Tax Reform Act of 1986. Journal of Accounting Research 30(Supplement): 161-185.

Shevlin, T. 2002. Commentary on Corporate Tax Shelters and Book-Tax Differences. Tax Law Review 55: 427-443.

Sufi, A. 2007. Information Asymmetry and Financing Arrangements: Evidence from Syndicated Loans. Journal of Finance 62(2): 629-668.

Tax Executives Institute (TEI). 2006. TEI Opposes Public Disclosure of Corporate Tax Returns. The Tax Executive 58(3): 241-243.

Taylor, A. and A. Sansone. 2007. The Handbook of Loan Syndications \& Trading. First Edition. The McGraw-Hill Companies, Inc.: New York, NY.

Thomas, J. and F. Zhang. 2011. Tax Expense Momentum. Journal of Accounting Research 49(3): 791-821.

Thomas, J. and F. Zhang. 2014. Valuation of Tax Expense. Review of Accounting Studies 19: 1436-1467.

Thompson Reuters. 2014. Global Syndicated Loans Review: Managing Underwriters. Thompson Reuters: New York, NY.

van Binsbergen, J. and C. Opp. 2016. Real Anomalies: Are Financial Markets a Sideshow? Working paper, University of Pennsylvania.

Walker, P. 2016. Multinationals to Publicly Declare Country-By-Country Profits and Tax. The Guardian September 6, 2016.

Weber, D. 2009. Do Analysts and Investors Fully Appreciate the Implications of Book-Tax Differences for Future Earnings? Contemporary Accounting Research 26(4): 1175-1206.

Wooldridge, J. 2010. Econometric Analysis of Cross Section and Panel Data. Second Edition. The MIT Press: Cambridge, MA. 
Table 1, Panel A: Descriptive Statistics

\begin{tabular}{|c|c|c|c|c|}
\hline & $\mathrm{N}$ & Mean & Median & Std. Dev \\
\hline \multicolumn{5}{|c|}{ Return Variables } \\
\hline RRET & 23,080 & 0.189 & 0.082 & 0.728 \\
\hline$M R E T$ & 23,080 & 0.084 & -0.019 & 0.680 \\
\hline FFRET & 19,333 & -0.643 & -0.960 & 0.538 \\
\hline LRET & 22,228 & 0.188 & 0.081 & 0.708 \\
\hline \multicolumn{5}{|c|}{ Difference-in-Differences Variables } \\
\hline INST & 26,472 & 0.206 & 0.000 & 0.405 \\
\hline POST & 26,472 & 0.636 & 1.000 & 0.481 \\
\hline \multicolumn{5}{|c|}{ Primary Variables } \\
\hline$T E$ & 24,766 & 0.023 & 0.022 & 0.062 \\
\hline$P T I$ & 24,769 & 0.063 & 0.070 & 13.508 \\
\hline$\triangle T E$ & 24,733 & 0.032 & 0.002 & 4.253 \\
\hline$\triangle P T I$ & 24,737 & 0.099 & 0.011 & 4.268 \\
\hline TSUR & 25,647 & 0.002 & 0.000 & 0.038 \\
\hline$T I B I$ & 25,191 & 0.596 & 0.584 & 1.169 \\
\hline TCCE & 16,641 & 0.000 & 0.000 & 0.029 \\
\hline$R T C C$ & 16,609 & -0.002 & 0.000 & 0.018 \\
\hline$N B T D$ & 25,140 & -0.020 & 0.000 & 0.067 \\
\hline$P B T D$ & 25,135 & -0.019 & 0.000 & 0.045 \\
\hline \multicolumn{5}{|c|}{ Control Variables } \\
\hline IOPCT & 26,472 & 0.357 & 0.259 & 0.361 \\
\hline$E P R$ & 26,044 & -0.214 & 0.041 & 2.017 \\
\hline CFPR & 23,973 & 0.133 & 0.090 & 0.408 \\
\hline PTACC & 23,701 & -0.060 & -0.050 & 0.187 \\
\hline$S P I$ & 26,288 & -0.018 & 0.000 & 0.073 \\
\hline$N O L$ & 26,288 & 0.149 & 0.000 & 0.949 \\
\hline BTM & 26,089 & 0.513 & 0.494 & 2.128 \\
\hline BETA & 19,428 & 0.010 & 0.010 & 0.009 \\
\hline$R V O L$ & 19,428 & 0.162 & 0.154 & 0.066 \\
\hline$L M V E$ & 26,089 & 5.866 & 5.892 & 2.012 \\
\hline GASUR & 23,704 & 0.021 & 0.007 & 0.293 \\
\hline ESUR & 25,651 & 0.009 & 0.005 & 0.319 \\
\hline SSUR & 25,651 & 0.080 & 0.044 & 0.615 \\
\hline$D X F I N$ & 21,577 & 0.107 & -0.003 & 0.790 \\
\hline$A N C O V$ & 26,472 & 1.483 & 1.540 & 0.972 \\
\hline ISPEC & 26,472 & 0.362 & 0.000 & 0.481 \\
\hline$R E S T$ & 26,472 & 0.200 & 0.000 & 0.400 \\
\hline$S E C D$ & 26,472 & 0.603 & 1.000 & 0.489 \\
\hline
\end{tabular}

Note: All continuous variables are winsorized by year at the $1^{\text {st }}$ and $99^{\text {th }}$ percentiles. Variables are defined in Appendix B. 
Table 1, Panel B: Test of Differences in Means

\begin{tabular}{|c|c|c|c|c|c|c|c|c|}
\hline \multirow{3}{*}{ RRET } & \multicolumn{4}{|c|}{ By Loan Type } & \multicolumn{4}{|c|}{ Pre- vs. Post Loan Issuance } \\
\hline & INST $=0$ & INST $=1$ & Diff. & t stat. & POST $=0$ & $\mathrm{POST}=1$ & Diff. & t stat. \\
\hline & 0.183 & 0.212 & -0.030 & $-2.50 * *$ & 0.206 & 0.178 & 0.028 & $2.88 * * *$ \\
\hline FFRET & -0.644 & -0.641 & -0.003 & -0.30 & -0.819 & -0.544 & -0.275 & $-35.15 * * *$ \\
\hline LRET & 0.184 & 0.202 & -0.018 & -1.54 & 0.228 & 0.164 & 0.064 & $6.52 * * *$ \\
\hline INST & 0.000 & 1.000 & -1.000 & N/A & 0.066 & 0.287 & -0.221 & $-44.26 * * *$ \\
\hline POST & 0.572 & 0.884 & -0.312 & $-44.26^{* * *}$ & 0.000 & 1.000 & -1.000 & $\mathrm{~N} / \mathrm{A}$ \\
\hline$T E$ & 0.024 & 0.019 & 0.004 & $4.12 * * *$ & 0.027 & 0.020 & 0.007 & $8.71 * * *$ \\
\hline PTI & 0.098 & -0.073 & 0.172 & 0.81 & 0.041 & 0.076 & -0.034 & -0.19 \\
\hline$\triangle T E$ & 0.039 & 0.007 & 0.032 & 0.48 & 0.006 & 0.046 & -0.040 & -0.71 \\
\hline$\triangle P T I$ & 0.087 & 0.148 & -0.061 & -0.91 & 0.052 & 0.125 & -0.073 & -1.29 \\
\hline TSUR & 0.002 & 0.002 & 0.000 & -0.35 & 0.003 & 0.001 & 0.002 & $3.09 * * *$ \\
\hline$T I B I$ & 0.630 & 0.463 & 0.167 & $9.16^{* * *}$ & 0.717 & 0.526 & 0.191 & $12.49 * * *$ \\
\hline TCCE & 0.001 & 0.000 & 0.001 & $1.94 *$ & 0.001 & 0.000 & 0.001 & 1.21 \\
\hline RTCC & -0.001 & -0.003 & 0.001 & $3.45^{* * *}$ & -0.001 & -0.002 & 0.001 & $2.92 * * *$ \\
\hline$N B T D$ & -0.020 & -0.021 & 0.002 & 1.59 & -0.020 & -0.020 & 0.001 & 0.59 \\
\hline$P B T D$ & -0.018 & -0.022 & 0.004 & $5.81 * * *$ & -0.017 & -0.019 & 0.002 & $3.52 * * *$ \\
\hline IOPCT & 0.325 & 0.483 & -0.158 & $-29.35^{* * *}$ & 0.216 & 0.438 & -0.222 & $-50.44 * * *$ \\
\hline$E P R$ & -0.173 & -0.370 & 0.197 & $6.39 * * *$ & -0.039 & -0.313 & 0.274 & $10.56^{* * *}$ \\
\hline CFPR & 0.119 & 0.186 & -0.067 & $-10.41 * * *$ & 0.120 & 0.140 & -0.020 & $-3.65^{* * *}$ \\
\hline PTACC & -0.058 & -0.071 & 0.014 & $4.61 * * *$ & -0.044 & -0.069 & 0.025 & $9.79 * * *$ \\
\hline$S P I$ & -0.018 & -0.020 & 0.003 & $2.26^{* *}$ & -0.016 & -0.020 & 0.004 & $3.93 * * *$ \\
\hline$N O L$ & 0.155 & 0.126 & 0.029 & $2.00 * *$ & 0.141 & 0.154 & -0.012 & -1.02 \\
\hline$B T M$ & 0.554 & 0.353 & 0.201 & $6.19 * * *$ & 0.622 & 0.451 & 0.171 & $6.25 * * *$ \\
\hline BETA & 0.010 & 0.011 & -0.001 & $-4.22 * * *$ & 0.010 & 0.010 & 0.000 & -1.49 \\
\hline$R V O L$ & 0.158 & 0.176 & -0.018 & $-15.48 * * *$ & 0.166 & 0.159 & 0.007 & $7.12 * * *$ \\
\hline$L M V E$ & 5.794 & 6.144 & -0.350 & $-11.43^{* * *}$ & 5.551 & 6.045 & -0.494 & $-19.17 * * *$ \\
\hline GASUR & 0.020 & 0.023 & -0.002 & -0.53 & 0.019 & 0.021 & -0.002 & -0.61 \\
\hline ESUR & 0.006 & 0.017 & -0.010 & $-2.13 * *$ & 0.013 & 0.006 & 0.007 & $1.76^{*}$ \\
\hline SSUR & 0.077 & 0.092 & -0.015 & -1.63 & 0.081 & 0.079 & 0.002 & 0.22 \\
\hline$D X F I N$ & 0.099 & 0.137 & -0.038 & $-2.83 * * *$ & 0.138 & 0.089 & 0.049 & $4.41 * * *$ \\
\hline$A N C O V$ & 1.475 & 1.515 & -0.040 & $-2.70 * * *$ & 1.384 & 1.540 & -0.155 & $-12.55 * * *$ \\
\hline
\end{tabular}




\begin{tabular}{lllll|lllr}
$I S P E C$ & 0.329 & 0.492 & -0.164 & $-22.65 * * *$ & 0.275 & 0.412 & -0.137 & $-22.52 * * *$ \\
$R E S T$ & 0.133 & 0.457 & -0.325 & $-56.59 * * *$ & 0.135 & 0.237 & -0.101 & $-19.98^{* * *}$ \\
$S E C D$ & 0.540 & 0.845 & -0.305 & $-42.42 * * *$ & 0.518 & 0.652 & -0.134 & $-21.58^{* * *}$ \\
\hline
\end{tabular}

Note: This table reports tests of differences in means between firms issuing institutional and non-institutional loans (first four columns) and observations pre- vs. post-loan issuance (last four columns). The number of observations associated with any variable ranges from 13,580 to 21,007 in column 1 , 3,029 to 5,465 in column $2,6,550$ to 9,624 in column 5 , and 10,059 to 16,848 in column $6 .{ }^{*}, * *$, and $* * *$ denote statistical significance at the $p<0.10$, 0.05 , and 0.01 levels (two-tailed), respectively. Continuous variables are winsorized at $1^{\text {st }}$ and $99^{\text {th }}$ percentiles. Variables are defined in Appendix B. 
Table 2, Panel A: Tax Response Coefficient Analysis

\begin{tabular}{|c|c|c|c|}
\hline \multirow{2}{*}{ Non-institutional Loan } & Pre Loan Issuance & Post Loan Issuance & Differences \\
\hline & $\begin{array}{c}0.116^{* * *} \\
(3.37)\end{array}$ & $\begin{array}{c}0.069^{* * *} \\
(5.75)\end{array}$ & $\begin{array}{l}-0.047 \\
(1.34)\end{array}$ \\
\hline Institutional Loan & $\begin{array}{l}-0.068 \\
(0.55)\end{array}$ & $\begin{array}{l}0.055^{* *} \\
(2.00)\end{array}$ & $\begin{array}{l}0.123 \\
(0.98)\end{array}$ \\
\hline Differences & $\begin{array}{l}-0.184 \\
(1.43)\end{array}$ & $\begin{array}{l}-0.014 \\
(0.46)\end{array}$ & $\begin{array}{l}0.170 \\
(1.31)\end{array}$ \\
\hline
\end{tabular}

Note: This table reports the coefficient estimates for TE from Eq. (1), based on the regression in column 1 of Panel D. All coefficients are standardized (by demeaning all variables and dividing them by their standard deviation before performing the regression), so they can be interpreted as the change in returns for a standard deviation change in TE. Absolute $\mathrm{t}$ statistics are reported in parentheses (all based on twotailed t-tests). ${ }^{*}, * *$, and $* * *$ denote statistical significance at the $p<0.10,0.05$, and 0.01 levels (twotailed), respectively.

Table 2, Panel B: Tax Response Coefficient Analysis - High Discretionary Accrual Firms

\begin{tabular}{l|c|c|c}
\multicolumn{1}{c}{} & Pre Loan Issuance & Post Loan Issuance & Differences \\
\cline { 2 - 4 } Non-institutional Loan & $0.132^{* * *}$ & $0.094^{* * *}$ & -0.038 \\
\multirow{3}{*}{ Institutional Loan } & $(4.63)$ & $(3.77)$ & $(1.07)$ \\
\cline { 2 - 4 } Differences & $-0.211^{*}$ & $0.154^{* *}$ & $0.365^{* * *}$ \\
& $(1.78)$ & $(3.67)$ & $(2.94)$ \\
\cline { 2 - 4 } & $-0.343^{* * *}$ & 0.060 & $0.402^{* * *}$ \\
& $(2.81)$ & $(1.25)$ & $(3.12)$ \\
\hline
\end{tabular}

Note: This table reports the coefficient estimates for $T E$ from Eq. (1), based on the regression in column 3 of Panel $\mathrm{D}$ that is estimated only for firms with high discretionary accruals, i.e. HIDA $=1$. All coefficients are standardized (by demeaning all variables and dividing them by their standard deviation before performing the regression), so they can be interpreted as the change in returns for a standard deviation change in TE. Absolute $t$ statistics are reported in parentheses (all based on two-tailed t-tests). $*$, **, and $* * *$ denote statistical significance at the $p<0.10,0.05$, and 0.01 levels (two-tailed), respectively.

Table 2, Panel C: Tax Response Coefficient Analysis - Low Discretionary Accrual Firms

\begin{tabular}{l|c|c|c}
\multicolumn{1}{c}{} & Pre Loan Issuance & Post Loan Issuance & Differences \\
\cline { 2 - 4 } Non-institutional Loan & $0.129^{* *}$ & $0.050^{* *}$ & -0.079 \\
\multirow{3}{*}{ Institutional Loan } & $(2.44)$ & $(2.55)$ & $(1.42)$ \\
\cline { 2 - 4 } Differences & -0.067 & -0.005 & 0.062 \\
& $(0.36)$ & $(0.13)$ & $(0.33)$ \\
\cline { 2 - 4 } & -0.196 & -0.055 & 0.141 \\
& $(1.01)$ & $(1.23)$ & $(0.72)$ \\
\hline
\end{tabular}

Note: This table reports the coefficient estimates for $T E$ from Eq. (1), based on the regression in column 4 of Panel $\mathrm{D}$ that is estimated only for firms with low discretionary accruals, i.e. HIDA $=0$. All coefficients are standardized (by demeaning all variables and dividing them by their standard deviation before performing the regression), so they can be interpreted as the change in returns for a standard deviation change in TE. Absolute t statistics are reported in parentheses (all based on two-tailed t-tests). 
$*, * *$, and $* * *$ denote statistical significance at the $p<0.10,0.05$, and 0.01 levels (two-tailed), respectively. 
Table 2, Panel D: Tax Response Coefficient Regressions

\begin{tabular}{|c|c|c|c|c|c|c|c|c|c|c|}
\hline $\begin{array}{l}\text { Dependent Variable: } \\
\text { RRET }\end{array}$ & (1) & (2) & $\begin{array}{c}(3) \\
H I D A=1\end{array}$ & $\begin{array}{c}(4) \\
H I D A=0\end{array}$ & $\begin{array}{c}(5) \\
H I D A=1\end{array}$ & $\begin{array}{c}(6) \\
H I D A=0\end{array}$ & $\begin{array}{c}(7) \\
H I D A=1\end{array}$ & $\begin{array}{c}(8) \\
H I D A=0\end{array}$ & $\begin{array}{c}(9) \\
H I D A=1\end{array}$ & $\begin{array}{c}(10) \\
H I D A=0\end{array}$ \\
\hline INST & $\begin{array}{l}0.063 \\
(1.30)\end{array}$ & $\begin{array}{l}0.021 \\
(0.47)\end{array}$ & $\begin{array}{l}-0.065 \\
(0.97)\end{array}$ & $\begin{array}{l}0.123 \\
(1.40)\end{array}$ & $\begin{array}{l}-0.062 \\
(1.31)\end{array}$ & $\begin{array}{l}0.074 \\
(0.93)\end{array}$ & $\begin{array}{l}0.028 \\
(0.44)\end{array}$ & $\begin{array}{l}0.043 \\
(0.55)\end{array}$ & $\begin{array}{l}0.022 \\
(0.43)\end{array}$ & $\begin{array}{l}0.021 \\
(0.29)\end{array}$ \\
\hline POST & $\begin{array}{c}-0.049^{* * *} \\
(3.66)\end{array}$ & $\begin{array}{c}-0.054^{* * *} \\
(4.17)\end{array}$ & $\begin{array}{l}-0.031 \\
(1.57)\end{array}$ & $\begin{array}{c}-0.066^{* * *} \\
(2.80)\end{array}$ & $\begin{array}{r}-0.034^{*} \\
(1.71)\end{array}$ & $\begin{array}{c}-0.060^{* * *} \\
(2.68)\end{array}$ & $\begin{array}{l}-0.012 \\
(0.40)\end{array}$ & $\begin{array}{l}-0.002 \\
(0.06)\end{array}$ & $\begin{array}{l}-0.011 \\
(0.38)\end{array}$ & $\begin{array}{l}-0.018 \\
(0.55)\end{array}$ \\
\hline$I N S T \times P O S T$ & $\begin{array}{l}-0.035 \\
(0.73)\end{array}$ & $\begin{array}{l}0.001 \\
(0.03)\end{array}$ & $\begin{array}{l}0.087 \\
(1.18)\end{array}$ & $\begin{array}{l}-0.085 \\
(1.02)\end{array}$ & $\begin{array}{l}0.088^{*} \\
(1.68)\end{array}$ & $\begin{array}{r}-0.044 \\
(0.57)\end{array}$ & $\begin{array}{l}-0.004 \\
(0.06)\end{array}$ & $\begin{array}{l}-0.030 \\
(0.39)\end{array}$ & $\begin{array}{l}0.015 \\
(0.26)\end{array}$ & $\begin{array}{l}-0.031 \\
(0.43)\end{array}$ \\
\hline$T E$ & $\begin{array}{c}0.116^{* * *} \\
(3.37)\end{array}$ & & $\begin{array}{c}0.132^{* * *} \\
(4.63)\end{array}$ & $\begin{array}{l}0.129^{* *} \\
(2.44)\end{array}$ & & & $\begin{array}{c}0.088^{* * *} \\
(2.74)\end{array}$ & $\begin{array}{l}0.056 \\
(1.04)\end{array}$ & & \\
\hline$I N S T \times T E$ & $\begin{array}{l}-0.184 \\
(1.43)\end{array}$ & & $\begin{array}{c}-0.343^{* * *} \\
(2.81)\end{array}$ & $\begin{array}{l}-0.196 \\
(1.01)\end{array}$ & & & $\begin{array}{l}-0.257^{*} \\
(1.96)\end{array}$ & $\begin{array}{l}-0.135 \\
(0.74)\end{array}$ & & \\
\hline$P O S T \times T E$ & $\begin{array}{l}-0.047 \\
(1.34)\end{array}$ & & $\begin{array}{l}-0.038 \\
(1.07)\end{array}$ & $\begin{array}{l}-0.079 \\
(1.42)\end{array}$ & & & $\begin{array}{l}-0.062^{*} \\
(1.69)\end{array}$ & $\begin{array}{l}-0.036 \\
(0.64)\end{array}$ & & \\
\hline$I N S T \times P O S T \times T E$ & $\begin{array}{l}0.170 \\
(1.31)\end{array}$ & & $\begin{array}{c}0.402^{* * *} \\
(3.12)\end{array}$ & $\begin{array}{l}0.141 \\
(0.72)\end{array}$ & & & $\begin{array}{l}0.402^{* * *} \\
(2.91)\end{array}$ & $\begin{array}{l}\mathbf{0 . 0 7 7} \\
\mathbf{( 0 . 4 1 )}\end{array}$ & & \\
\hline$P T I$ & $\begin{array}{l}0.057 \\
(1.25)\end{array}$ & & $\begin{array}{l}0.057 \\
(1.13)\end{array}$ & $\begin{array}{l}0.054 \\
(0.97)\end{array}$ & & & $\begin{array}{l}0.036 \\
(0.71)\end{array}$ & $\begin{array}{l}0.041 \\
(0.58)\end{array}$ & & \\
\hline$I N S T \times P T I$ & $\begin{array}{c}-0.194^{* *} \\
(2.00)\end{array}$ & & $\begin{array}{l}0.451 \\
(1.41)\end{array}$ & $\begin{array}{c}-0.243^{* *} \\
(2.06)\end{array}$ & & & $\begin{array}{l}0.297 \\
(1.06)\end{array}$ & $\begin{array}{c}-0.223^{* *} \\
(2.04)\end{array}$ & & \\
\hline$P O S T \times P T I$ & $\begin{array}{l}-0.008 \\
(0.17)\end{array}$ & & $\begin{array}{l}-0.010 \\
(0.17)\end{array}$ & $\begin{array}{l}-0.006 \\
(0.10)\end{array}$ & & & $\begin{array}{l}0.044 \\
(0.73)\end{array}$ & $\begin{array}{l}-0.029 \\
(0.39)\end{array}$ & & \\
\hline$I N S T \times P O S T \times P T I$ & $\begin{array}{l}0.176^{*} \\
(1.77)\end{array}$ & & $\begin{array}{l}-0.431 \\
(1.34)\end{array}$ & $\begin{array}{l}0.225^{*} \\
(1.78)\end{array}$ & & & $\begin{array}{c}-0.360 \\
(1.28)\end{array}$ & $\begin{array}{l}0.182 \\
(1.48)\end{array}$ & & \\
\hline$\triangle T E$ & & $\begin{array}{c}0.044 \\
(1.44)\end{array}$ & & & $\begin{array}{c}0.057^{*} \\
(1.86)\end{array}$ & $\begin{array}{l}0.037 \\
(0.83)\end{array}$ & & & $\begin{array}{c}0.068^{* *} \\
(2.21)\end{array}$ & $\begin{array}{l}-0.008 \\
(0.19)\end{array}$ \\
\hline$I N S T \times \Delta T E$ & & $\begin{array}{l}0.045 \\
(0.67)\end{array}$ & & & $\begin{array}{c}-0.263^{* * *} \\
(2.82)\end{array}$ & $\begin{array}{l}0.080 \\
(0.92)\end{array}$ & & & $\begin{array}{c}-0.253^{* *} \\
(2.35)\end{array}$ & $\begin{array}{l}0.129 \\
(1.58)\end{array}$ \\
\hline$P O S T \times \triangle T E$ & & $\begin{array}{l}0.003 \\
(0.08)\end{array}$ & & & $\begin{array}{c}-0.006 \\
(0.14)\end{array}$ & $\begin{array}{l}0.015 \\
(0.30)\end{array}$ & & & $\begin{array}{l}-0.039 \\
(0.94)\end{array}$ & $\begin{array}{l}0.027 \\
(0.56)\end{array}$ \\
\hline$I N S T \times P O S T \times \triangle T E$ & & $\begin{array}{r}-0.087 \\
(1.18)\end{array}$ & & & $\begin{array}{c}0.249^{* * *} \\
(2.41)\end{array}$ & $\begin{array}{c}-0.173^{*} \\
(1.83)\end{array}$ & & & $\begin{array}{c}0.279^{* * *} \\
(2.32)\end{array}$ & $\begin{array}{c}-0.208^{* * *} \\
(2.33)\end{array}$ \\
\hline$\triangle P T I$ & & $\begin{array}{c}0.259^{* * *} \\
(4.73)\end{array}$ & & & $\begin{array}{c}0.183^{* * *} \\
(3.03)\end{array}$ & $\begin{array}{c}0.319^{* * * *} \\
(4.81)\end{array}$ & & & $\begin{array}{l}0.079 \\
(1.50)\end{array}$ & $\begin{array}{c}0.413^{* * * *} \\
(7.04)\end{array}$ \\
\hline
\end{tabular}




\begin{tabular}{|c|c|c|c|c|c|c|c|c|c|c|}
\hline$I N S T \times \triangle P T I$ & & $\begin{array}{c}-0.117^{*} \\
(1.94)\end{array}$ & & & $\begin{array}{c}0.450^{* * *} \\
(4.02)\end{array}$ & $\begin{array}{c}-0.190^{* * *} \\
(2.81)\end{array}$ & & & $\begin{array}{c}0.428^{* * *} \\
(3.97)\end{array}$ & $\begin{array}{c}-0.308^{* * *} \\
(5.06)\end{array}$ \\
\hline$P O S T \times \triangle P T I$ & & $-0.142^{* *}$ & & & -0.076 & $-0.146^{*}$ & & & 0.033 & $-0.173^{* *}$ \\
\hline$I N S T \times P O S T \times \triangle P T I$ & & $\begin{array}{l}(2.38) \\
\mathbf{0 . 1 6 1}^{* *}\end{array}$ & & & 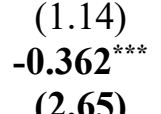 & $\begin{array}{c}(1.89) \\
0.261^{* * *}\end{array}$ & & & $\begin{array}{c}(0.55) \\
-\mathbf{0 . 4 2 0}\end{array}$ & $\mathbf{0 . 3 0 6}^{* * * *}$ \\
\hline IOPCT & $\begin{array}{c}-0.228^{* * *} \\
(12.57)\end{array}$ & $\begin{array}{c}-0.185^{* * *} \\
(10.91)\end{array}$ & $\begin{array}{c}-0.200^{* * *} \\
(7.19)\end{array}$ & $\begin{array}{c}-0.254^{* * *} \\
(8.16)\end{array}$ & $\begin{array}{c}-0.170^{* * *} \\
(6.30)\end{array}$ & $\begin{array}{c}-0.189^{* * *} \\
(6.58)\end{array}$ & $\begin{array}{c}-0.184^{* * *} \\
(6.25)\end{array}$ & $\begin{array}{c}-0.177^{* * *} \\
(5.20)\end{array}$ & $\begin{array}{c}-0.179^{* * *} \\
(6.08)\end{array}$ & $\begin{array}{c}-0.156^{* * *} \\
(4.89)\end{array}$ \\
\hline$S P I$ & & & & & & & $\begin{array}{c}0.033^{* *} \\
(2.21)\end{array}$ & $\begin{array}{c}0.045^{* * *} \\
(3.20)\end{array}$ & $\begin{array}{c}0.032^{* *} \\
(2.25)\end{array}$ & $\begin{array}{l}-0.019 \\
(1.56)\end{array}$ \\
\hline$N O L$ & & & & & & & $\begin{array}{l}0.032 \\
(1.35)\end{array}$ & $\begin{array}{c}0.035^{* *} \\
(2.02)\end{array}$ & $\begin{array}{l}0.021 \\
(0.93)\end{array}$ & $\begin{array}{c}0.035^{* *} \\
(2.13)\end{array}$ \\
\hline BTM & & & & & & & $\begin{array}{c}-0.055^{* *} \\
(2.11)\end{array}$ & $\begin{array}{c}-0.070^{* * * *} \\
(3.54)\end{array}$ & $\begin{array}{c}-0.045^{* *} \\
(2.17)\end{array}$ & $\begin{array}{c}-0.058^{* * * *} \\
(3.28)\end{array}$ \\
\hline BETA & & & & & & & $\begin{array}{r}-0.009 \\
(0.72)\end{array}$ & $\begin{array}{l}0.020 \\
(1.34)\end{array}$ & $\begin{array}{c}-0.004 \\
(0.35)\end{array}$ & $\begin{array}{l}0.006 \\
(0.45)\end{array}$ \\
\hline$R V O L$ & & & & & & & $\begin{array}{c}0.188^{* * *} \\
(7.94)\end{array}$ & $\begin{array}{c}0.268^{* * *} \\
(9.31)\end{array}$ & $\begin{array}{c}0.163^{* * *} \\
(6.89)\end{array}$ & $\begin{array}{c}0.197^{* * *} \\
(8.73)\end{array}$ \\
\hline$L M V E$ & & & & & & & $\begin{array}{c}0.385^{* * *} \\
(8.14)\end{array}$ & $\begin{array}{c}0.561^{* * *} \\
(11.74)\end{array}$ & $\begin{array}{c}0.447^{* * *} \\
(10.64)\end{array}$ & $\begin{array}{c}0.526^{* * *} \\
(12.88)\end{array}$ \\
\hline$A N C O V$ & & & & & & & $\begin{array}{c}-0.241^{* * *} \\
(10.13)\end{array}$ & $\begin{array}{c}-0.251^{* * *} \\
(9.30)\end{array}$ & $\begin{array}{c}-0.244^{* * *} \\
(10.59)\end{array}$ & $\begin{array}{c}-0.213^{* * *} \\
(8.55)\end{array}$ \\
\hline ISPEC & & & & & & & $\begin{array}{r}-0.041 \\
(1.41)\end{array}$ & $\begin{array}{c}-0.074^{*} \\
(1.72)\end{array}$ & $\begin{array}{l}-0.045 \\
(1.54)\end{array}$ & $\begin{array}{c}-0.080^{* *} \\
(2.08)\end{array}$ \\
\hline$I S P E C \times P O S T$ & & & & & & & $\begin{array}{l}0.052^{*} \\
(1.75)\end{array}$ & $\begin{array}{l}0.030 \\
(0.69)\end{array}$ & $\begin{array}{l}0.051^{*} \\
(1.77)\end{array}$ & $\begin{array}{l}0.042 \\
(1.09)\end{array}$ \\
\hline$R E S T$ & & & & & & & $\begin{array}{l}-0.008 \\
(0.22)\end{array}$ & $\begin{array}{l}0.039 \\
(0.76)\end{array}$ & $\begin{array}{l}-0.009 \\
(0.24)\end{array}$ & $\begin{array}{l}0.019 \\
(0.38)\end{array}$ \\
\hline$R E S T \times P O S T$ & & & & & & & $\begin{array}{l}0.001 \\
(0.03)\end{array}$ & $\begin{array}{l}-0.045 \\
(0.90)\end{array}$ & $\begin{array}{l}-0.007 \\
(0.18)\end{array}$ & $\begin{array}{l}-0.035 \\
(0.75)\end{array}$ \\
\hline$S E C D$ & & & & & & & $\begin{array}{l}0.006 \\
(0.20)\end{array}$ & $\begin{array}{l}0.053 \\
(1.29)\end{array}$ & $\begin{array}{l}0.008 \\
(0.27)\end{array}$ & $\begin{array}{l}0.043 \\
(1.13)\end{array}$ \\
\hline$S E C D \times P O S T$ & & & & & & & $\begin{array}{l}-0.010 \\
(0.32)\end{array}$ & $\begin{array}{r}-0.050 \\
(1.22)\end{array}$ & $\begin{array}{l}-0.011 \\
(0.33)\end{array}$ & $\begin{array}{l}-0.027 \\
(0.73)\end{array}$ \\
\hline Intercept & $\begin{array}{c}0.242^{* * *} \\
(8.31)\end{array}$ & $\begin{array}{c}0.209^{* * *} \\
(7.39)\end{array}$ & $\begin{array}{c}0.248^{* * *} \\
(5.54)\end{array}$ & $\begin{array}{c}0.311^{* * *} \\
(6.02)\end{array}$ & $\begin{array}{c}0.203^{* * *} \\
(4.66)\end{array}$ & $\begin{array}{c}0.255^{* * *} \\
(5.12)\end{array}$ & $\begin{array}{c}0.268^{* * * *} \\
(4.87)\end{array}$ & $\begin{array}{c}0.253^{* * *} \\
(3.62)\end{array}$ & $\begin{array}{c}0.189^{* * *} \\
(3.45)\end{array}$ & $\begin{array}{c}0.193^{* * * *} \\
(3.03)\end{array}$ \\
\hline
\end{tabular}




\begin{tabular}{|c|c|c|c|c|c|c|c|c|c|c|}
\hline Observations & 22,376 & 22,360 & 10,236 & 10,209 & 10,236 & 10,209 & 8,783 & 8,864 & 8,783 & 8,864 \\
\hline Adjusted $R^{2}$ & 0.208 & 0.244 & 0.211 & 0.225 & 0.217 & 0.296 & 0.281 & 0.305 & 0.287 & 0.380 \\
\hline
\end{tabular}

Note: This table reports the estimates of Eq. (1) using raw buy-and-hold returns as the dependent variable. Columns 3, 5, 7, and 9 (columns 4, 6,

8 , and 10) are estimated only for firms with high (low) discretionary accruals, i.e. HIDA $=1(H I D A=0)$. All coefficients for continuous variables are standardized (by demeaning all variables and dividing them by their standard deviation before performing the regression), so they can be interpreted as the change in returns for a standard deviation change in the continuous independent variable. Firm and year fixed effects are included in all specifications and robust standard errors clustered by firm are used. Absolute $t$ statistics are reported in parentheses (all based on two-tailed t-tests). $* * *$, and $* * *$ denote statistical significance at the $p<0.10,0.05$, and 0.01 levels (two-tailed), respectively. All continuous variables are winsorized by year at the $1^{\text {st }}$ and $99^{\text {th }}$ percentiles. All variables are defined in Appendix B. 
Table 3: Tax Response Coefficient Analysis Partitioned Pre/Post Schedule M-3 Implementation

\begin{tabular}{|c|c|c|c|c|}
\hline $\begin{array}{l}\text { Dependent Variable: } \\
\text { RRET }\end{array}$ & $\begin{array}{c}(1) \\
M 3 P O S T=0\end{array}$ & $\begin{array}{c}(2) \\
M 3 P O S T=1\end{array}$ & $\begin{array}{c}(3) \\
M 3 P O S T=0\end{array}$ & $\begin{array}{c}(4) \\
M 3 P O S T=1\end{array}$ \\
\hline INST & $\begin{array}{c}-0.008 \\
(0.10)\end{array}$ & $\begin{array}{l}0.066 \\
(0.77)\end{array}$ & $\begin{array}{l}0.026 \\
(0.36)\end{array}$ & $\begin{array}{c}-0.001 \\
(0.01)\end{array}$ \\
\hline POST & $\begin{array}{l}-0.057^{* * * *} \\
(2.82)\end{array}$ & $\begin{array}{r}-0.013 \\
(0.50)\end{array}$ & $\begin{array}{l}-0.072^{* * * *} \\
(3.67)\end{array}$ & $\begin{array}{l}-0.025 \\
(1.09)\end{array}$ \\
\hline$I N S T \times P O S T$ & $\begin{array}{l}0.105 \\
(1.37)\end{array}$ & $\begin{array}{l}-0.016 \\
(0.20)\end{array}$ & $\begin{array}{l}0.079 \\
(1.11)\end{array}$ & $\begin{array}{l}0.023 \\
(0.28)\end{array}$ \\
\hline$T E$ & $\begin{array}{l}0.172^{* * *} \\
(8.23)\end{array}$ & $\begin{array}{r}-0.028 \\
(0.33)\end{array}$ & & \\
\hline$I N S T \times T E$ & $\begin{array}{l}-0.283^{* * * *} \\
(260)\end{array}$ & $\begin{array}{c}-0.001 \\
(0.01)\end{array}$ & & \\
\hline$P O S T \times T E$ & $\begin{array}{l}-0.063^{* *} \\
(2.45)\end{array}$ & $\begin{array}{l}0.026 \\
(0.29)\end{array}$ & & \\
\hline$I N S T \times P O S T \times T E$ & $\begin{array}{l}0.223^{* *} \\
(1.99)\end{array}$ & $\begin{array}{l}0.083 \\
(0.34)\end{array}$ & & \\
\hline PTI & $\begin{array}{l}0.091^{* *} \\
(2.43)\end{array}$ & $\begin{array}{l}0.175 \\
(1.37)\end{array}$ & & \\
\hline$I N S T \times P T I$ & $\begin{array}{l}0.331 \\
(1.40)\end{array}$ & $\begin{array}{l}-0.395^{* *} \\
(2.26)\end{array}$ & & \\
\hline$P O S T \times P T I$ & $\begin{array}{l}-0.058 \\
(1.43)\end{array}$ & $\begin{array}{l}-0.126 \\
(1.01)\end{array}$ & & \\
\hline$I N S T \times P O S T \times P T I$ & $\begin{array}{r}-\mathbf{0 . 3 5 3} \\
(\mathbf{1 . 4 8 )}\end{array}$ & $\begin{array}{l}\mathbf{0 . 3 4 6} \\
(\mathbf{1 . 9 4})\end{array}$ & & \\
\hline$\triangle T E$ & & & $\begin{array}{l}0.103^{* * *} \\
(4.64)\end{array}$ & $\begin{array}{l}0.001 \\
(0.01)\end{array}$ \\
\hline$I N S T \times \Delta T E$ & & & $\begin{array}{l}-0.156^{* *} \\
(2.10)\end{array}$ & $\begin{array}{l}0.109 \\
(0.58)\end{array}$ \\
\hline$P O S T \times \Delta T E$ & & & $\begin{array}{l}-0.072^{* * *} \\
(2.60)\end{array}$ & $\begin{array}{l}0.050 \\
(0.88)\end{array}$ \\
\hline$I N S T \times P O S T \times \triangle T E$ & & & $\begin{array}{l}\mathbf{0 . 1 2 9}^{*} \\
(1.67)\end{array}$ & $\begin{array}{r}-0.141 \\
(0.68)\end{array}$ \\
\hline$\triangle P T I$ & & & $\begin{array}{l}0.202^{* * * *} \\
(5.52)\end{array}$ & $\begin{array}{l}0.540^{* * * *} \\
(6.56)\end{array}$ \\
\hline$I N S T \times \triangle P T I$ & & & $\begin{array}{l}0.163 \\
(155)\end{array}$ & $\begin{array}{l}-0.362^{* * * *} \\
(3.20)\end{array}$ \\
\hline$P O S T \times \triangle P T I$ & & & $\begin{array}{l}-0.116^{* *} \\
(2.54)\end{array}$ & $\begin{array}{c}-0.404^{* * *} \\
(4.36)\end{array}$ \\
\hline$I N S T \times P O S T \times \triangle P T I$ & & & $\begin{array}{c}-0.178 \\
(1.56)\end{array}$ & $\begin{array}{c}\mathbf{0 . 4 4 8} 8^{k * * *} \\
(3.40)\end{array}$ \\
\hline IOPCT & $\begin{array}{l}-0.151^{* * *} \\
(6.15)\end{array}$ & $\begin{array}{l}-0.189^{* * *} \\
(7.15)\end{array}$ & $\begin{array}{l}-0.141^{* * * *} \\
(5.90)\end{array}$ & $\begin{array}{c}-0.137^{* * * *} \\
(5.64)\end{array}$ \\
\hline Intercept & $\begin{array}{l}1.043^{* * *} \\
(11.54)\end{array}$ & $\begin{array}{l}0.027 \\
(0.77)\end{array}$ & $\begin{array}{l}0.996^{* * *} \\
(11.23)\end{array}$ & $\begin{array}{l}0.058^{*} \\
(1.73)\end{array}$ \\
\hline $\begin{array}{l}\text { Observations } \\
\text { Adjusted } R^{2}\end{array}$ & $\begin{array}{c}11,140 \\
0.123\end{array}$ & $\begin{array}{l}7,483 \\
0.322\end{array}$ & $\begin{array}{c}11,124 \\
0.127\end{array}$ & $\begin{array}{l}7,483 \\
0.410\end{array}$ \\
\hline
\end{tabular}

Note: This table reports the estimates of Eq. (1) using raw buy-and-hold returns as the dependent 
variable. Columns 1 and 3 are estimated only for syndicated loan issuances occurring in 2001 or earlier, so that the entire six-year window occurs pre Schedule M-3 implementation. Columns 2 and 4 are estimated only for syndicated loan issuances occurring in 2007 or later, so that the entire six-year window occurs post Schedule M-3 implementation. All coefficients for continuous variables are standardized (by demeaning all variables and dividing them by their standard deviation before performing the regression), so they can be interpreted as the change in returns for a standard deviation change in the continuous independent variable. Firm and year fixed effects are included in all specifications and robust standard errors clustered by firm are used. Absolute $t$ statistics are reported in parentheses (all based on two-tailed t-tests). $* * *$, and $* * *$ denote statistical significance at the $p<0.10,0.05$, and 0.01 levels (two-tailed), respectively. All continuous variables are winsorized by year at the $1^{\text {st }}$ and $99^{\text {th }}$ percentiles. All variables are defined in Appendix B. 
Table 4, Panel A: Tax Surprise (TSUR) Anomaly Analysis

\begin{tabular}{l|c|c|c}
\multicolumn{1}{c}{} & \multicolumn{1}{c}{ Pre Loan Issuance } & Post Loan Issuance & \multicolumn{1}{c}{ Differences } \\
\cline { 2 - 4 } Non-institutional Loan & -0.016 & -0.003 & 0.013 \\
& $-4.42 \%$ & $-0.83 \%$ & $3.59 \%$ \\
\multirow{4}{*}{ Institutional Loan } & $(2.13)$ & $(0.36)$ & $(1.41)$ \\
\cline { 2 - 4 } & 0.025 & -0.016 & $-0.041^{*}$ \\
& $6.90 \%$ & $-4.42 \%$ & $-11.32 \%$ \\
Differences & $(1.17)$ & $(2.08)$ & $(1.80)$ \\
& $0.041^{*}$ & -0.014 & $-0.054^{* *}$ \\
& $11.32 \%$ & $3.86 \%$ & $(2.15)$ \\
\cline { 2 - 4 } & $(1.77)$ & $(1.37)$ & \\
\hline
\end{tabular}

Note: This table reports the coefficient estimates for TSUR from Eq. (2), based on the regression in column 1 of Panel G. All coefficients are standardized (by demeaning all variables and dividing them by their standard deviation before performing the regression), so they can be interpreted as the change in returns for a standard deviation change in TSUR. Anomaly returns are computed by multiplying the relevant standardized coefficient by an adjustment factor, which is the number of standard deviations that separate the $5^{\text {th }}$ and $95^{\text {th }}$ percentiles of TSUR (2.76). The $5^{\text {th }}$ and $95^{\text {th }}$ percentiles were chosen for ease in comparing returns across prior literature, given the prevalence of using decile-ranked anomaly variables in prior literature and that the $5^{\text {th }}$ and $95^{\text {th }}$ percentiles lie midway in the first and tenth decile. Absolute $\mathrm{t}$ statistics are reported in parentheses (all based on two-tailed t-tests). *, **, and *** denote statistical significance at the $p<0.10,0.05$, and 0.01 levels (two-tailed), respectively, while $\dagger$, $\dagger \dagger$, and $\dagger \dagger \dagger$ denote statistical significance at the $p<0.10,0.05$, and 0.01 levels (one-tailed), respectively. I use one-tailed tests for the main effects of the anomaly given the significant prior evidence of tax anomalies (e.g., Thomas and Zhang 2011).

Table 4, Panel B: Lev and Nissim (TIBI) Anomaly Analysis

\begin{tabular}{l|c|c|c}
\multicolumn{1}{c}{} & \multicolumn{1}{c}{ Pre Loan Issuance } & Post Loan Issuance & Differences \\
\cline { 2 - 4 } Non-institutional Loan & 0.001 & 0.005 & 0.004 \\
& $0.21 \%$ & $1.06 \%$ & $0.85 \%$ \\
\multirow{4}{*}{ Institutional Loan } & $(0.11)$ & $(0.53)$ & $(0.30)$ \\
\cline { 2 - 4 } Differences & $0.040^{\dagger \dagger \dagger}$ & 0.003 & $-0.037^{* *}$ \\
& $8.48 \%$ & $0.64 \%$ & $-7.84 \%$ \\
& $(2.84)$ & $(0.55)$ & $(2.36)$ \\
\cline { 2 - 4 } & $0.039^{* *}$ & -0.002 & $-0.041^{* *}$ \\
& $8.27 \%$ & $0.42 \%$ & $(2.06)$ \\
\hline
\end{tabular}

Note: This table reports the coefficient estimates for TIBI from Eq. (2), based on the regression in column 2 of Panel G. All coefficients are standardized (by demeaning all variables and dividing them by their standard deviation before performing the regression), so they can be interpreted as the change in returns for a standard deviation change in TIBI. Anomaly returns are computed by multiplying the relevant standardized coefficient by an adjustment factor, which is the number of standard deviations that separate the $5^{\text {th }}$ and $95^{\text {th }}$ percentiles of TIBI (2.12). The $5^{\text {th }}$ and $95^{\text {th }}$ percentiles were chosen for ease in comparing returns across prior literature, given the prevalence of using decile-ranked anomaly variables in prior literature and that the $5^{\text {th }}$ and $95^{\text {th }}$ percentiles lie midway in the first and tenth decile. Absolute $t$ statistics are reported in parentheses (all based on two-tailed t-tests). $*, * *$, and $* * *$ denote statistical significance at the $p<0.10,0.05$, and 0.01 levels (two-tailed), respectively, while $\dagger$, $\dagger \dagger$, and $\uparrow \dagger \dagger$ denote statistical significance at the $p<0.10,0.05$, and 0.01 levels (one-tailed), respectively. I use one-tailed tests for the 
main effects of the anomaly given the significant prior evidence of tax anomalies (e.g., Lev and Nissim 2004).

Table 4, Panel C: Tax Change Component (TCCE) Anomaly Analysis

\begin{tabular}{l|c|c|c}
\multicolumn{1}{c}{} & \multicolumn{1}{c}{ Pre Loan Issuance } & Post Loan Issuance & Differences \\
\cline { 2 - 4 } Non-institutional Loan & -0.008 & -0.004 & 0.004 \\
& $-1.10 \%$ & $-0.55 \%$ & $0.55 \%$ \\
\multirow{4}{*}{ Institutional Loan } & $(1.43)$ & $(0.55)$ & $(0.48)$ \\
\cline { 2 - 4 } & $0.018^{\dagger}$ & -0.002 & $-0.020^{*}$ \\
\multirow{3}{*}{ Differences } & $2.48 \%$ & $-0.28 \%$ & $-2.76 \%$ \\
& $(1.62)$ & $(0.33)$ & $-0.73)$ \\
\cline { 2 - 4 } & $0.026^{* *}$ & 0.002 & $(1.66)$ \\
\hline
\end{tabular}

Note: This table reports the coefficient estimates for TCCE from Eq. (2), based on the regression in column 3 of Panel G. All coefficients are standardized (by demeaning all variables and dividing them by their standard deviation before performing the regression), so they can be interpreted as the change in returns for a standard deviation change in TCCE. Anomaly returns are computed by multiplying the relevant standardized coefficient by an adjustment factor, which is the number of standard deviations that separate the $5^{\text {th }}$ and $95^{\text {th }}$ percentiles of TCCE $(1.38)$. The $5^{\text {th }}$ and $95^{\text {th }}$ percentiles were chosen for ease in comparing returns across prior literature, given the prevalence of using decile-ranked anomaly variables in prior literature and that the $5^{\text {th }}$ and $95^{\text {th }}$ percentiles lie midway in the first and tenth decile. Absolute $t$ statistics are reported in parentheses (all based on two-tailed t-tests). ${ }^{*}, * *$, and $* * *$ denote statistical significance at the $p<0.10,0.05$, and 0.01 levels (two-tailed), respectively, while $\dagger, \uparrow \dagger$, and $\dagger \dagger \dagger$ denote statistical significance at the $p<0.10,0.05$, and 0.01 levels (one-tailed), respectively. I use one-tailed tests for the main effects of the anomaly given the significant prior evidence of tax anomalies (e.g., Schmidt 2006).

Table 4, Panel D: Revised Tax Change (RTCC) Anomaly Analysis

\begin{tabular}{l|c|c|c}
\cline { 2 - 3 } Non-institutional Loan & -0.024 & 0.004 & $0.028^{* *}$ \\
& $-3.19 \%$ & $0.53 \%$ & $3.72 \%$ \\
\multirow{4}{*}{ Institutional Loan } & $(2.30)$ & $(0.47)$ & $(2.42)$ \\
\cline { 2 - 4 } Differences & $0.023^{\dagger \dagger \dagger}$ & 0.004 & $-0.019^{*}$ \\
& $3.06 \%$ & $0.53 \%$ & $-2.53 \%$ \\
& $(2.83)$ & $(0.53)$ & $(1.70)$ \\
\cline { 2 - 4 } & $0.047^{* * * *}$ & 0.001 & $-0.047^{* * *}$ \\
& $6.25 \%$ & $0.01 \%$ & $(2.87)$ \\
\hline
\end{tabular}

Note: This table reports the coefficient estimates for $R T C C$ from Eq. (2), based on the regression in column 4 of Panel G. All coefficients are standardized (by demeaning all variables and dividing them by their standard deviation before performing the regression), so they can be interpreted as the change in returns for a standard deviation change in $R T C C$. Anomaly returns are computed by multiplying the relevant standardized coefficient by an adjustment factor, which is the number of standard deviations that separate the $5^{\text {th }}$ and $95^{\text {th }}$ percentiles of RTCC $(1.33)$. The $5^{\text {th }}$ and $95^{\text {th }}$ percentiles were chosen for ease in comparing returns across prior literature, given the prevalence of using decile-ranked anomaly 
variables in prior literature and that the $5^{\text {th }}$ and $95^{\text {th }}$ percentiles lie midway in the first and tenth decile. Absolute $\mathrm{t}$ statistics are reported in parentheses (all based on two-tailed t-tests). ${ }^{*}, * *$, and $* * *$ denote statistical significance at the $p<0.10,0.05$, and 0.01 levels (two-tailed), respectively, while $\dagger, \dagger \uparrow$, and $\uparrow \dagger \dagger$ denote statistical significance at the $p<0.10,0.05$, and 0.01 levels (one-tailed), respectively. I use one-tailed tests for the main effects of the anomaly given the significant prior evidence of tax anomalies (e.g., Schmidt 2006).

\section{Table 4, Panel E: Negative Book-Tax Difference (NBTD) Anomaly Analysis}

\section{Non-institutional Loan \\ Institutional Loan}

\section{Differences}

\begin{tabular}{|c|c|c|}
\multicolumn{1}{c}{ Pre Loan Issuance } & Post Loan Issuance & Differences \\
\hline-0.017 & 0.003 & $0.020^{*}$ \\
$-2.33 \%$ & $0.41 \%$ & $2.74 \%$ \\
$(1.98)$ & $(0.49)$ & $(1.91)$ \\
\hline $0.020^{\dagger \dagger}$ & 0.005 & -0.015 \\
$2.74 \%$ & $0.69 \%$ & $-2.05 \%$ \\
$(1.92)$ & $(0.62)$ & $(1.17)$ \\
\hline $0.036^{* * *}$ & 0.002 & $-0.035^{* *}$ \\
$4.93 \%$ & $0.28 \%$ & $(2.11)$ \\
$(2.82)$ & $(0.16)$ & \\
\hline
\end{tabular}

Note: This table reports the coefficient estimates for NBTD from Eq. (2), based on the regression in column 5 of Panel G. All coefficients are standardized (by demeaning all variables and dividing them by their standard deviation before performing the regression), so they can be interpreted as the change in returns for a standard deviation change in NBTD. Anomaly returns are computed by multiplying the relevant standardized coefficient by an adjustment factor, which is the number of standard deviations that separate the $5^{\text {th }}$ and $95^{\text {th }}$ percentiles of NBTD (1.37). The $5^{\text {th }}$ and $95^{\text {th }}$ percentiles were chosen for ease in comparing returns across prior literature, given the prevalence of using decile-ranked anomaly variables in prior literature and that the $5^{\text {th }}$ and $95^{\text {th }}$ percentiles lie midway in the first and tenth decile. Absolute $\mathrm{t}$ statistics are reported in parentheses (all based on two-tailed t-tests). ${ }^{*}, * *$, and $* * *$ denote statistical significance at the $p<0.10,0.05$, and 0.01 levels (two-tailed), respectively, while $\dagger, \dagger \dagger$, and $\dagger \dagger \dagger$ denote statistical significance at the $p<0.10,0.05$, and 0.01 levels (one-tailed), respectively. I use one-tailed tests for the main effects of the anomaly given the significant prior evidence of tax anomalies (e.g., Hanlon 2005).

\section{Table 4, Panel F: Positive Book-Tax Difference (PBTD) Placebo Anomaly Analysis}

\begin{tabular}{l|c|c|c}
\multicolumn{1}{c}{} & Pre Loan Issuance & Post Loan Issuance & Differences \\
\cline { 2 - 4 } Non-institutional Loan & 0.010 & -0.002 & -0.012 \\
& $1.87 \%$ & $-0.37 \%$ & $-2.24 \%$ \\
\multirow{3}{*}{ Institutional Loan } & $(1.24)$ & $(0.28)$ & $(1.14)$ \\
\cline { 2 - 4 } Differences & -0.005 & 0.011 & 0.016 \\
& $-0.94 \%$ & $2.06 \%$ & $2.99 \%$ \\
& $(0.28)$ & $(1.36)$ & $(0.78)$ \\
\cline { 2 - 4 } & -0.015 & 0.013 & 0.029 \\
& $-2.81 \%$ & $2.43 \%$ & $(1.23)$ \\
\hline
\end{tabular}

Note: This table reports the coefficient estimates for PBTD from Eq. (2), based on the regression in column 6 of Panel G. All coefficients are standardized (by demeaning all variables and dividing them by their standard deviation before performing the regression), so they can be interpreted as the change in 
returns for a standard deviation change in PBTD. Anomaly returns are computed by multiplying the relevant standardized coefficient by an adjustment factor, which is the number of standard deviations that separate the $5^{\text {th }}$ and $95^{\text {th }}$ percentiles of PBTD (1.87). The $5^{\text {th }}$ and $95^{\text {th }}$ percentiles were chosen for ease in comparing returns across prior literature, given the prevalence of using decile-ranked anomaly variables in prior literature and that the $5^{\text {th }}$ and $95^{\text {th }}$ percentiles lie midway in the first and tenth decile. Absolute $\mathrm{t}$ statistics are reported in parentheses (all based on two-tailed t-tests). *, **, and *** denote statistical significance at the $p<0.10,0.05$, and 0.01 levels (two-tailed), respectively. 
Table 4, Panel G: Tax Anomaly Regressions

\begin{tabular}{|c|c|c|c|c|c|c|}
\hline & $(1)$ & $(2)$ & (3) & $(4)$ & $(5)$ & $(6)$ \\
\hline$T A X:$ & TSUR & $T I B I$ & TCCE & $R T C C$ & $N B T D$ & $P B T D$ \\
\hline Dependent Variable: & FFRET & FFRET & FFRET & FFRET & FFRET & FFRET \\
\hline \multirow[t]{2}{*}{ INST } & -0.001 & -0.000 & -0.015 & -0.012 & -0.001 & -0.004 \\
\hline & $(0.05)$ & $(0.01)$ & $(0.74)$ & $(0.58)$ & $(0.03)$ & $(0.16)$ \\
\hline \multirow[t]{2}{*}{ POST } & $0.057^{* *}$ & $0.065^{* * *}$ & $0.051^{* *}$ & $0.058^{* *}$ & $0.065^{* * *}$ & $0.063^{* *}$ \\
\hline & $(2.38)$ & $(2.59)$ & $(2.17)$ & $(2.54)$ & $(2.59)$ & $(2.53)$ \\
\hline \multirow[t]{2}{*}{$I N S T \times P O S T$} & 0.003 & 0.004 & 0.001 & -0.002 & 0.004 & 0.008 \\
\hline & $(0.14)$ & $(0.17)$ & $(0.04)$ & $(0.08)$ & $(0.17)$ & $(0.35)$ \\
\hline \multirow[t]{2}{*}{$T A X$} & $-0.016^{* *}$ & 0.001 & -0.008 & $-0.024^{* *}$ & $-0.017^{* *}$ & 0.010 \\
\hline & $(2.13)$ & $(0.11)$ & $(1.43)$ & $(2.30)$ & $(1.98)$ & $(1.24)$ \\
\hline \multirow[t]{2}{*}{$I N S T \times T A X$} & $0.041^{*}$ & $0.039^{* *}$ & $0.026^{* *}$ & $0.047^{* * * *}$ & $0.036^{* * * *}$ & -0.015 \\
\hline & (1.77) & $(2.29)$ & $(2.20)$ & $(3.85)$ & $(2.82)$ & $(0.76)$ \\
\hline \multirow[t]{2}{*}{$P O S T \times T A X$} & 0.013 & 0.004 & 0.004 & $0.028^{* *}$ & $0.020^{*}$ & -0.012 \\
\hline & $(1.41)$ & $(0.30)$ & $(0.48)$ & $(2.42)$ & $(1.91)$ & $(1.14)$ \\
\hline \multirow[t]{2}{*}{$I N S T \times P O S T \times T A X$} & $-0.054^{* *}$ & $-0.041^{* *}$ & $-0.024^{*}$ & $-0.047^{* * *}$ & $-0.035^{* *}$ & 0.029 \\
\hline & $(2.15)$ & $(2.06)$ & (1.66) & (2.87) & (2.11) & $(1.23)$ \\
\hline \multirow[t]{2}{*}{ LRET } & 0.009 & 0.008 & 0.008 & 0.009 & 0.008 & 0.008 \\
\hline & $(1.53)$ & $(1.37)$ & $(1.31)$ & $(1.37)$ & $(1.32)$ & $(1.35)$ \\
\hline \multirow[t]{2}{*}{$E P R$} & $-0.079^{* * *}$ & $-0.080^{* * *}$ & 0.002 & 0.003 & $-0.080^{* * *}$ & $-0.080^{* * *}$ \\
\hline & $(3.51)$ & $(3.54)$ & $(0.19)$ & $(0.36)$ & (3.53) & $(3.52)$ \\
\hline \multirow[t]{2}{*}{ CFPR } & 0.003 & 0.001 & 0.012 & 0.011 & 0.001 & 0.001 \\
\hline & $(0.38)$ & $(0.14)$ & $(1.38)$ & $(1.21)$ & $(0.14)$ & $(0.17)$ \\
\hline \multirow[t]{2}{*}{ PTACC } & 0.012 & 0.008 & 0.006 & 0.005 & 0.007 & 0.008 \\
\hline & $(1.40)$ & $(0.91)$ & $(0.77)$ & $(0.64)$ & $(0.83)$ & $(0.94)$ \\
\hline \multirow[t]{2}{*}{$S P I$} & -0.005 & -0.004 & $-0.012^{* *}$ & $-0.012^{* *}$ & -0.005 & -0.003 \\
\hline & $(0.53)$ & $(0.47)$ & $(2.14)$ & $(2.21)$ & $(0.51)$ & $(0.33)$ \\
\hline \multirow[t]{2}{*}{$N O L$} & -0.005 & -0.005 & -0.004 & -0.004 & -0.006 & -0.006 \\
\hline & $(0.80)$ & $(0.53)$ & $(0.79)$ & $(0.83)$ & $(0.58)$ & $(0.60)$ \\
\hline \multirow[t]{2}{*}{ BTM } & 0.024 & 0.026 & 0.000 & 0.000 & 0.026 & 0.026 \\
\hline & $(1.20)$ & $(1.31)$ & $(0.00)$ & $(0.03)$ & (1.31) & $(1.28)$ \\
\hline \multirow[t]{2}{*}{ BETA } & $-0.054^{* * *}$ & $-0.055^{* * *}$ & $-0.053^{* * *}$ & $-0.053^{* * *}$ & $-0.055^{* * *}$ & $-0.055^{* * *}$ \\
\hline & $(10.14)$ & $(10.23)$ & $(8.10)$ & $(8.29)$ & $(10.22)$ & (10.19) \\
\hline \multirow[t]{2}{*}{$R V O L$} & 0.005 & 0.006 & 0.006 & 0.007 & 0.006 & 0.005 \\
\hline & $(0.56)$ & $(0.72)$ & $(0.78)$ & $(0.89)$ & $(0.70)$ & $(0.62)$ \\
\hline \multirow[t]{2}{*}{$L M V E$} & $-0.024^{*}$ & -0.022 & $-0.036^{* * *}$ & $-0.036^{* * *}$ & -0.021 & -0.022 \\
\hline & $(1.84)$ & $(1.65)$ & $(2.82)$ & $(2.80)$ & $(1.58)$ & $(1.62)$ \\
\hline \multirow[t]{2}{*}{ GASUR } & -0.000 & -0.013 & -0.004 & -0.005 & -0.012 & -0.013 \\
\hline & $(0.04)$ & (1.40) & $(0.69)$ & $(0.79)$ & $(1.34)$ & $(1.40)$ \\
\hline \multirow[t]{2}{*}{ ESUR } & 0.007 & 0.002 & 0.002 & 0.003 & 0.004 & 0.002 \\
\hline & $(0.89)$ & $(0.28)$ & $(0.38)$ & $(0.74)$ & $(0.44)$ & $(0.24)$ \\
\hline \multirow[t]{2}{*}{$S S U R$} & 0.010 & 0.015 & 0.003 & 0.003 & 0.014 & 0.015 \\
\hline & (1.36) & (1.61) & $(0.44)$ & $(0.40)$ & $(1.56)$ & $(1.62)$ \\
\hline \multirow[t]{2}{*}{ DXFIN } & -0.003 & -0.003 & -0.004 & -0.004 & -0.003 & -0.003 \\
\hline & $(1.21)$ & $(1.23)$ & (1.14) & (1.16) & $(1.15)$ & $(1.06)$ \\
\hline IOPCT & 0.004 & 0.002 & -0.009 & -0.010 & 0.002 & 0.002 \\
\hline & $(0.37)$ & $(0.25)$ & $(0.68)$ & $(0.70)$ & $(0.24)$ & $(0.24)$ \\
\hline$A N C O V$ & 0.008 & 0.006 & 0.016 & 0.017 & 0.006 & 0.006 \\
\hline & $(0.93)$ & $(0.72)$ & $(1.44)$ & $(1.46)$ & $(0.72)$ & $(0.75)$ \\
\hline
\end{tabular}




\begin{tabular}{lcccccc} 
ISPEC & 0.046 & 0.051 & $0.037^{*}$ & $0.040^{*}$ & 0.050 & 0.050 \\
& $(1.45)$ & $(1.58)$ & $(1.66)$ & $(1.79)$ & $(1.55)$ & $(1.56)$ \\
$I S P E C \times P O S T$ & -0.047 & $-0.056^{*}$ & -0.035 & -0.038 & $-0.056^{*}$ & $-0.056^{*}$ \\
& $(1.50)$ & $(1.76)$ & $(1.36)$ & $(1.47)$ & $(1.75)$ & $(1.75)$ \\
$R E S T$ & -0.006 & -0.008 & 0.023 & 0.023 & -0.007 & -0.009 \\
& $(0.26)$ & $(0.34)$ & $(1.25)$ & $(1.22)$ & $(0.30)$ & $(0.38)$ \\
$R E S T \times P O S T$ & 0.021 & 0.024 & 0.004 & 0.006 & 0.022 & 0.024 \\
SECD & $(0.81)$ & $(0.89)$ & $(0.18)$ & $(0.26)$ & $(0.83)$ & $(0.91)$ \\
& 0.016 & 0.023 & 0.004 & 0.008 & 0.023 & 0.023 \\
SECD $\times$ POST & $(0.75)$ & $(1.03)$ & $(0.19)$ & $(0.38)$ & $(1.00)$ & $(1.02)$ \\
& -0.040 & $-0.050^{*}$ & -0.015 & -0.019 & $-0.049^{*}$ & $-0.049^{*}$ \\
Intercept & $(1.55)$ & $(1.86)$ & $(0.67)$ & $(0.86)$ & $(1.81)$ & $(1.84)$ \\
& $-0.213^{*}$ & $-0.209^{*}$ & -0.133 & -0.138 & $-0.214^{* *}$ & $-0.213^{* *}$ \\
\hline Observations & $(1.94)$ & $(1.92)$ & $(1.33)$ & $(1.39)$ & $(1.97)$ & $(1.98)$ \\
Adjusted $R^{2}$ & 14,196 & 13,764 & 9,866 & 9,840 & 13,764 & 13,764 \\
\hline
\end{tabular}

Note: This table reports the estimates of Eq. (2) using Fama-French (2014) abnormal returns as the dependent variable in the top panel. All coefficients for continuous variables are standardized (by demeaning all variables and dividing them by their standard deviation before performing the regression), so they can be interpreted as the change in returns for a standard deviation change in the continuous independent variable. Industry and year fixed effects are included in all specifications and robust standard errors clustered by firm are used. Absolute $t$ statistics are reported in parentheses (all based on two-tailed t-tests). $*, * *$, and $* * *$ denote statistical significance at the $p<0.10,0.05$, and 0.01 levels (two-tailed), respectively. All continuous variables are winsorized by year at the $1^{\text {st }}$ and $99^{\text {th }}$ percentiles. All variables are defined in Appendix B. 
Table 5: Tax Anomaly Regressions Partitioned Post/Pre Schedule M-3 Implementation

\begin{tabular}{|c|c|c|c|c|c|c|c|c|c|c|}
\hline \multirow{4}{*}{$\begin{array}{l}\text { TAX: } \\
\text { Dependent Variable: }\end{array}$} & \multicolumn{5}{|c|}{$M 3 P O S T=0$} & \multicolumn{5}{|c|}{$M 3 P O S T=1$} \\
\hline & (1) & (2) & (3) & (4) & (5) & (6) & (7) & (8) & (9) & (10) \\
\hline & TSUR & TIBI & TCCE & RTCC & NBTD & TSUR & TIBI & TCCE & RTCC & $N B T D$ \\
\hline & FFRET & FFRET & FFRET & FFRET & FFRET & FFRET & FFRET & FFRET & FFRET & FFRET \\
\hline \multirow[t]{2}{*}{ INST } & 0.004 & 0.004 & 0.003 & 0.003 & 0.004 & -0.036 & -0.026 & -0.015 & -0.012 & -0.026 \\
\hline & $(0.73)$ & $(0.77)$ & $(0.72)$ & $(0.79)$ & $(0.84)$ & $(0.63)$ & $(0.46)$ & $(0.29)$ & $(0.23)$ & $(0.45)$ \\
\hline \multirow[t]{2}{*}{ POST } & $0.022^{* * *}$ & $0.021^{* * *}$ & $0.022^{* * *}$ & $0.022^{* * *}$ & $0.021^{* * *}$ & 0.017 & 0.020 & 0.017 & 0.016 & 0.018 \\
\hline & $(6.76)$ & $(6.63)$ & $(6.13)$ & $(6.00)$ & $(6.52)$ & $(0.55)$ & $(0.64)$ & $(0.63)$ & $(0.59)$ & $(0.60)$ \\
\hline \multirow[t]{2}{*}{$I N S T \times P O S T$} & $-0.028^{* * *}$ & $-0.027^{* * *}$ & $-0.022^{* *}$ & $-0.022^{* *}$ & $-0.027^{* * *}$ & 0.077 & 0.069 & 0.041 & 0.038 & 0.069 \\
\hline & $(3.56)$ & $(3.26)$ & $(2.27)$ & $(2.31)$ & $(3.16)$ & $(1.27)$ & $(1.11)$ & $(0.71)$ & $(0.66)$ & $(1.10)$ \\
\hline \multirow[t]{2}{*}{$T A X$} & -0.002 & 0.000 & -0.001 & 0.000 & 0.001 & $-0.028^{*}$ & 0.009 & -0.010 & $-0.022^{* *}$ & -0.006 \\
\hline & $(1.54)$ & $(0.85)$ & $(0.75)$ & $(0.27)$ & $(0.65)$ & $(1.93)$ & $(0.64)$ & $(0.92)$ & $(2.32)$ & $(0.33)$ \\
\hline \multirow[t]{2}{*}{$I N S T \times T A X$} & 0.003 & -0.003 & $0.006^{*}$ & $0.004^{* *}$ & 0.002 & 0.065 & 0.063 & $0.044^{* *}$ & $0.050^{* * *}$ & 0.038 \\
\hline & $(0.55)$ & $(0.80)$ & $(1.90)$ & $(2.08)$ & $(0.82)$ & $(1.54)$ & $(1.54)$ & $(2.17)$ & $(3.73)$ & $(1.47)$ \\
\hline \multirow[t]{2}{*}{$P O S T \times T A X$} & $0.007^{* *}$ & -0.003 & 0.002 & -0.000 & 0.002 & $0.031^{*}$ & -0.002 & $0.034^{* *}$ & $0.023^{*}$ & 0.000 \\
\hline & $(2.04)$ & $(1.03)$ & $(1.01)$ & $(0.03)$ & $(0.85)$ & $(1.84)$ & $(0.16)$ & $(2.18)$ & $(1.89)$ & $(0.00)$ \\
\hline \multirow[t]{2}{*}{$I N S T \times P O S T \times T A X$} & $-0.013^{\text {** }}$ & 0.004 & $-0.014^{* * * *}$ & -0.011 & 0.000 & $-0.087^{*}$ & -0.058 & $-0.060^{* *}$ & $-0.038^{*}$ & -0.018 \\
\hline & $(2.04)$ & $(0.48)$ & $(2.63)$ & (1.13) & $(\mathbf{0 . 0 3 )}$ & (1.85) & $(1.34)$ & $(2.34)$ & $(1.76)$ & $(0.54)$ \\
\hline \multirow[t]{2}{*}{ Intercept } & $-0.734^{* * *}$ & $-0.730^{* * *}$ & $-0.719^{* * *}$ & $-0.721^{* * *}$ & $-0.730^{* * *}$ & -0.154 & -0.155 & -0.096 & -0.093 & -0.158 \\
\hline & $(23.97)$ & $(21.52)$ & $(24.84)$ & $(23.75)$ & $(21.40)$ & $(1.17)$ & $(1.16)$ & $(0.85)$ & $(0.82)$ & $(1.19)$ \\
\hline Controls & YES & YES & YES & YES & YES & YES & YES & YES & YES & YES \\
\hline Observations & 6,194 & 5,921 & 4,223 & 4,208 & 5,921 & 5,561 & 5,475 & 3,976 & 3,971 & 5,475 \\
\hline Adjusted $R^{2}$ & 0.553 & 0.550 & 0.569 & 0.569 & 0.551 & 0.558 & 0.556 & 0.665 & 0.664 & 0.556 \\
\hline
\end{tabular}

Note: This table reports the estimates of Eq. (2) using Fama-French (2014) abnormal returns as the dependent variable. Columns 1 through 5 are estimated only for syndicated loan issuances occurring in 2001 or earlier, so that the entire six-year window occurs pre Schedule M-3 implementation. Columns 6 through 10 are estimated only for syndicated loan issuances occurring in 2007 or later, so that the entire six-year window occurs post Schedule M-3 implementation. The $T A X$ coefficients are standardized (by demeaning all variables and dividing them by their standard deviation before performing the regression), so they can be interpreted as the change in returns for a standard deviation change in $T A X$. Industry and year fixed effects are included in all specifications and robust standard errors clustered by firm are used. Absolute $t$ statistics are reported in parentheses (all based on two-tailed t-tests). ${ }^{*}, * *$, and $* * *$ denote statistical significance at the $p<0.10,0.05$, and 0.01 levels (twotailed), respectively. All continuous variables are winsorized by year at the $1^{\text {st }}$ and $99^{\text {th }}$ percentiles. All variables are defined in Appendix B. 
Figure 1: Setting Disadvantages in Examining the Usefulness of Tax Return Information

\begin{tabular}{|c|c|c|c|c|}
\hline Disadvantage & $\begin{array}{c}\text { U.S. } \\
\text { Syndicated } \\
\text { Loans }\end{array}$ & Japan & Australia & $\begin{array}{l}\text { Scandinavian } \\
\text { Countries }\end{array}$ \\
\hline Taxable income and taxes payable not directly observable. & $\mathrm{X}$ & & & \\
\hline $\begin{array}{l}\text { Tax return items other than taxable income and taxes payable are not directly } \\
\text { observable. }\end{array}$ & $\mathrm{X}$ & $\mathrm{X}$ & $\mathrm{X}$ & $\mathrm{X}$ \\
\hline Limited time series of tax return disclosure events. & & & $\mathrm{X}$ & \\
\hline Tax return items are only made available to citizens. & & & & $\mathrm{X}$ \\
\hline Tax return items cannot be matched to specific firms or stock returns. & & $\mathrm{X}$ & & \\
\hline $\begin{array}{l}\text { Tax return disclosure is required only above a certain taxable income threshold, } \\
\text { which (a) can reduce the usefulness of tax information due to taxable income } \\
\text { manipulation and (b) means that firms whose tax return information is } \\
\text { observable may differ from other firms on a number of non-tax dimensions (e.g., } \\
\text { be larger or more profitable), making clean identification nearly impossible. }{ }^{60}\end{array}$ & & $\mathrm{X}$ & $\mathrm{X}$ & \\
\hline $\begin{array}{l}\text { Public disclosure of tax return items is subject to highly-negative public } \\
\text { sentiment about corporate taxation which can subconsciously bias investor } \\
\text { judgments and decisions (Elliott et al. 2014), meaning it is unclear whether and } \\
\text { to what degree any market response to the disclosure is due to new value- } \\
\text { relevant information versus irrational affective reactions. }\end{array}$ & & & $\mathrm{X}$ & \\
\hline $\begin{array}{l}\text { It is unclear whether any market reaction by rational investors is due to the } \\
\text { incremental usefulness of taxable income information to investors or due to } \\
\text { investors anticipating negative or positive reactions by consumers, suppliers, } \\
\text { regulators, and lawmakers to a firm's public taxable income disclosure. }\end{array}$ & & $\mathrm{X}$ & $\mathrm{X}$ & $\mathrm{X}$ \\
\hline
\end{tabular}

\footnotetext{
${ }^{60}$ A common technique to address the concern that companies above a taxable income threshold are fundamentally different from other companies is to use a regression discontinuity design. However, given significant prior evidence of market reactions to the information disclosed by similar firms (Foster 1981; Baginski 1987; Gleason et al. 2008), and that firms close to the reporting threshold from below are likely to have both significant information and sentiment spillover from similar firms above the threshold, using a regression discontinuity design could create a role for information and sentiment spillovers to affect market results related to tax disclosures. As such, there is no good control group in the Australian and Japanese settings to identify the usefulness of taxable income to investors.
} 